\title{
Quantitative Analysis of Geomorphometric Parameters of Wadi Kerak, Jordan, Using Remote Sensing and GIS
}

\author{
Yahya Farhan, Ali Anbar, Omar Enaba, Nisrin Al-Shaikh \\ Department of Geography, University of Jordan, Amman, Jordan \\ Email: yahyafarhan2100@outlook.com
}

Received 15 February 2015; accepted 9 April 2015; published 10 April 2015

Copyright (C) 2015 by authors and Scientific Research Publishing Inc.

This work is licensed under the Creative Commons Attribution International License (CC BY). http://creativecommons.org/licenses/by/4.0/

cc) (i) Open Access

\begin{abstract}
Geomorphometric analysis was carried out to illustrate the drainage characteristics and morphology of Wadi Kerak watershed, southern Jordan. The basic and derived morphometric parameters (linear, areal and relief aspects of drainage network) for the basin were determined using ASTER DEM (30 m resolution) and Geographic Information System (GIS). These parameters describe the basin drainage network, geometry, texture, and relief characteristics. The hypsometric curve, hypsometric integral and clinographic curve were also prepared using topographic maps of $1: 50,000$ scale. Findings have revealed that $W$. Kerak is in the youth-age stage of geomorphic evolution. Fluvial erosion associated with successive phases of rejuvenation plays a significant role in drainage basin development, whereas structure and tectonics, lithology and relief dictate the drainage pattern and morphological setting of the catchment. The drainage area of the watershed is $190.9 \mathrm{~km}^{2}$ and constitutes a $5^{\text {th }}$-order drainage basin. The commonly observed drainage patterns are the trellis type, with sub-dendritic pattern recognized in the upper catchment. The drainage pattern, and the semi-linear alignment of main and branching drainage indicate the prominent influence of the Kerak-Al-fiha fault system on the drainage network. High dissection, relative relief, relief ratio, steep slopes and breaks of slopes are characteristic of W. Kerak. Morphometric analysis reveals that four rejuvenation phases caused severe erosion and down cutting activity in the past, and it is still susceptible to surface erosion at present.
\end{abstract}

\section{Keywords}

ASTER DEM, Drainage Morphometry, Dissection Index, Rejuvenation, Hypsometric Analysis, Clinographic Curve 


\section{Introduction}

A drainage basin which is recognizable as being of fluvial erosive origin is considered a basic fundamental geomorphic, topographic and hydrologic areal unit for watershed management [1]. It is an ideal unit for management and sustainable development of natural resources. Adding to that, it implies the appropriate utilization of land and water resources of a watershed, for optimum production with minimum hazard to environmental resources, including people who live across the watershed [2]-[4]. A drainage basin represents a natural manageable hydrological entity which enables surface runoff to a defined channel, ravine, stream or river at a particular point [5]. More significantly, it provides the basis for geomorphometric analysis. A technique was introduced earlier by Horton [6] [7] and elaborated by Strahler [8]-[11], Smith [12], Miller [13] and Schumm [14], those who later established the quantitative fluvial geomorphic research [15].

Morphometry is defined as the measurement and mathematical evaluation of the configuration of the earth's surface, and of the shape and dimensions of its landforms. The main characteristics which are often analyzed are: area, altitude, volume, slope, profile and texture of the land, and other different aspects of drainage basins [16].

Conventional geomorphometric studies were carried out to explore the relationship between morphometric properties of drainage networks and climate, relief, lithology, structure and tectonics in order to interpret the morphometric parameters [15] [17]-[19]. The role of tectonic control on geomorphologcial processes in shaping drainage networks was reported for selected river basins from Kerala, Southern India [20]. In the recent past, morphometric analysis of stream networks was employed for a wide range of applications. Assessment of natural resources and geo-environmental hazard, especially flash floods for arid watersheds, was addressed particularly in developing countries, such as Egypt [21]-[23] and Turkey [24]. Groundwater recharge potentials from flash floods in arid land alluvial basins, southern Red Sea coast in Egypt, were also investigated [25]. Morphometric analysis techniques were adopted to evaluate groundwater potential and hydrological behavior of watersheds [26] [27]. Watershed prioritization for soil and water conservation measures [28] was implemented in several parts of India. Such applications confirm the role of geographic information system (GIS), remote sensing (RS) and morphometric analysis as an efficient tool for locating water harvesting structures by prioritizing mini-watersheds in Gujarat and western Ghats regions, India [4] [24] [29], and Bago River, Myanmar [2]. Studies regarding the identification of artificial recharge sites in Manchi basin, eastern Rajasthan, India were carried out using morphometric analysis and GIS techniques [30]. Analysis of drainage basin morphometry based on multivariate statistical methods was achieved to delimit morphological regions in south-west Uganda [31] [32]. Evaluation of geomorphometric characteristics was carried out on a catchment level in India [33] and on a regional level in the western Arabian Peninsula [34]. Assessment of surface runoff in arid and data-scarce regions in the Madinah, western Saudi Arabia was conducted to predict flood hazard [35]-[37], and to estimate erosion rates and sediment yield [38]. Moreover, the relationship between morphometric characteristics and specific hydrological parameters for selected drainage basins (southeastern Brazil) was examined using multivariate statistical techniques [39]. The morphometric parameters (linear, area, shape and relief) of drainage basins and subbasins, and their network properties, have been investigated using conventional manual methods, i.e. topographic maps (scales 1:25,000 and 1:50,000) and field observations in different environments [7] [8]-[13] [40] [41]. Since the mid-1980s, the development of geospatial analytical techniques (GIS and RS) and other software designed specifically to quantify and calculate linear, areal, shape and relief morphometric parameters [42] [43], along with increasing availability of digital elevation data, have enhanced the process of quantitative description of drainage networks, morphometric thematic mapping, and the applicability of geomorphometric analysis in different fields of research. Comparison and evaluation of morphometric data derived through conventional, manual methods, and automated geospatial techniques, indicate that modern technology provides powerful and cost-effective tools for managing and processing data and creating maps for different applications [24] [44] [45].

At present, digital elevation models (DEMs) provide the most standard technique to extract the required information which controls geomorphological processes. Furthermore, DEMs can be employed to delineate the drainage networks precisely with all first-order streams or the "fingertip" tributaries as described earlier by Horton [7]. Many researchers concluded that geographic information systems and remote sensing technology are efficient tools for measuring and calculating precise drainage basin morphometric parameters. Other advantages are the capabilities of managing and processing spatial information in large amounts accurately and in a timesaving manner [24] [44] [46]-[48]. 
The objectives of the present study are:

1) to analyze selected linear, areal, shape and relief parameters of the W. Kerak drainage basin using GIS, remote sensing and topographic maps;

2) characterization of drainage networks in relation to tectonic and structural disturbances, lithology, rejuvenation phases, landscape evolution and denudation chronology;

3) to identify major morphometric parameters which have a significant role on erosional landforms of the W. Kerak drainage basin; and,

4) to analyze distinct breaks of stream slope in relation to uplifting of the faulted/erosional scarp overlooking the rift floor and to relatively minor lithological variations. Findings provide valuable information that can be employed in assessing floods risk management through delimiting flood-prone terrain units, and selecting appropriate sites for water harvesting and in planning soil and conservation schemes. Morphometric analysis can also be applied to similar highland watersheds in southern and northern Jordan.

\section{Study Area}

Geomorphometric analysis was conducted in the W. Kerak watershed, southern Jordan. The study area lies to the south-east of the Dead Sea, east of the Lisan Peninsula. It is situated between E longitudes $35^{\circ} 30^{\prime}$ to $35^{\circ} 44^{\prime}$ and $\mathrm{N}$ latitudes $31^{\circ} 14^{\prime}$ to $31^{\circ} 17^{\prime}$. The catchment is located in the middle part of the Kerak Governorate (Figure 1). W. Kerak watershed covers an area of $190.9 \mathrm{~km}^{2}$. Terrain elevation varies from -410 meters below mean sea level close to the Dead Sea, and increases towards the east to 1000 meters at Kerak city, and then ascending to 1250 meters (a.s.l) in the upper catchment close to Mazar town. The watershed represents typical rift (Ghor)/ highland topography. In the Mazar and Kerak areas (the middle and upper catchment), the climate is classified

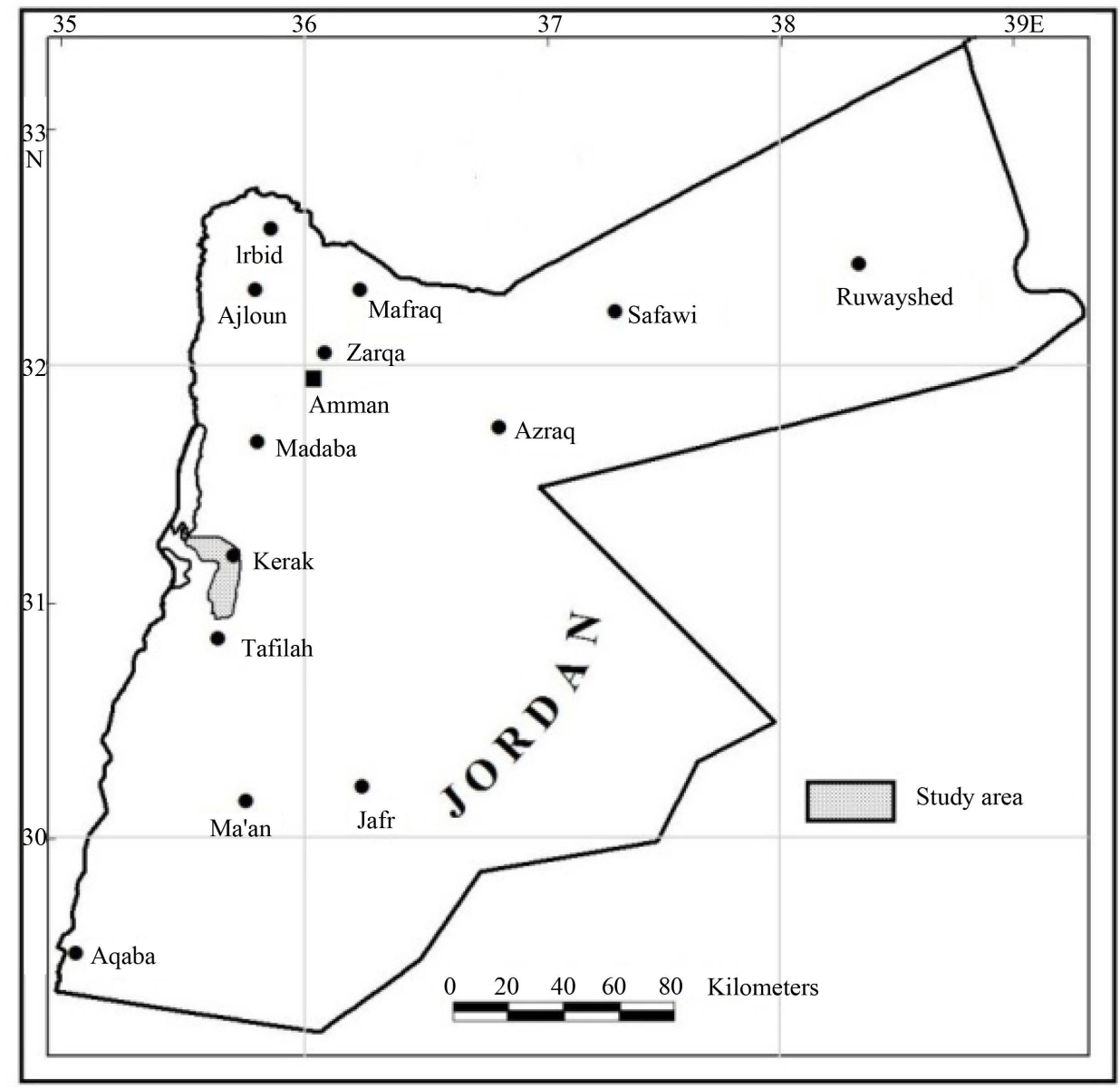

Figure 1. The study area. 
as dry Mediterranean, whereas in the lower part, or Ghor Mazra close to the Dead Sea it is arid. Mean annual rainfall ranges from $325 \mathrm{~mm}$ at Kerak to $290 \mathrm{~mm}$ at Mazar east of Kerak, and $77.5 \mathrm{~mm}$ at Ghor Mazra west of Kerak. Rainfall is concentrated in winter during the cold season (October to March). The average maximum and minimum temperatures are $17^{\circ} \mathrm{C}$ and $2^{\circ} \mathrm{C}$ in Kerak and Mazar respectively, while the average maximum temperature in Ghor Mazra is $32^{\circ} \mathrm{C}$ with summer months reaching $40^{\circ} \mathrm{C}$. In Mazar town, east of Kerak, part of the precipitation falls as snow. Several days of freezing temperatures (below $0.0^{\circ} \mathrm{C}$ ) are recorded between November and February. Progressive river incision and continuous rejuvenation of W. Kerak draining to the rift, associated with recurrent lowering of the base level (the Dead Sea), and uplifting of the scarp zone(during late Tertiary and Quaternary tectonics) produced irregular slope segments $\left(15^{\circ}-35^{\circ}\right)$ separated by rocky benches. The wadi profile also displays prominent irregularities which probably represent some forms of rejuvenation points. When major breaks of slopes combined with major longitudinal profile irregularities [49], four or five rejuvenation phases can be recognized. Rejuvenation phases have resulted in deeply dissected topography, dense incised drainage and over-steepened slopes. Therefore, the catchment is part of the Jordan highlands region, which witnessed problems of slope instability, soil erosion, deforestation and changing land cover. Clay loam, silty clay, silty clay loam and silty loam soils dominate most of the catchment [50] and are characterized by low permeability. Thus, runoff erosion is expected to be high. The vegetation cover is poor in the southern highlands compared with the northern highlands, due to the dominance of more arid conditions. Here low rainfall and greater marginality are characteristic phenomena. Population densities are lower, and nomads from the eastern Jordanian desert occasionally visit the southern highlands with their herds of camels, sheep and goats [51]. Therefore, overgrazing and poor conservation measures maximize soil erosion.

Geologically, the study area is covered by a wide range of rock types, ranging from late Cambrian sandstone to Quaternary deposits, including lacustrine Lisan Marl, alluvial fan of Ghor Mazra and the fluvial terraces of W. Kerak. The Kurnub sandstone (Lower Cretaceous) is exposed along the deeply incised middle course of the wadi. The sandstones are overlain by the Turonian-Cenomanian Ajlune group, which consists of two lithological units: the Nodular limestone unit (marly clay unit), which is predominantly marls and clays interbedded with marly limestones, nodular limestones and dolomites. Deferential erosion acting on intensely jointed and weathered marls and clays has caused slope instability. The Echinoidal limestone unit, or the limestone marl unit consists of limestones, dolomitic limestones, marl, sandy limestones, marly limestones and chert nodules. The third lithological unit (Eocene-Senonian rocks) dominate the watershed to the east of Kerak city. Various outcrops of limestones, marls, chalk, chert, phosphate, shales and clays are present [52]. The spatial distribution of these "soft rocks" represents a major factor influencing slope instability and soil erosion loss. W. Kerak is considered a part of the Kerak-Al-fiha fault system and the subsidiary dense branching faults to the north and south of W. Kerak main course. The major fault (early Miocene) is often obscured under the materials pertaining to old degraded landslide complexes [53]. Geomorphological units identified in the catchment include: structural plateau/ridges, remnants of planation surfaces, residual hills, denudational slopes, landslides zone, infilled valleys, glacis, fluvial terraces and badlands [54].

\section{Materials and Methods}

Geomorphometric analysis of W. Kerak catchment was carried out using topographic maps with scale 1:50,000 (20 m contour interval). The basin was divided into sub-watersheds 1 - 5 (Figure 2), and the drainage networks of the main watershed and sub-watershed were generated using ASTER DEM (30 m resolution), then digitized using Arc GIS 10.1 software package (Figure 3). The data extraction and data analysis were carried out in ERDAS Imagine 8.5, Arc GIS 10.1 and Terrain Analysis System (TAS). An assessment of the morphometric parameters for each drainage network was executed at a sub-basin level. The derived parameters were classified into five groups [42] such as basic, linear, areal, shape and relief aspects of the basin. The order was assigned to each stream following the stream ordering system developed by Strahler [8] [11]. The W. Kerak watershed was found to be of the fifth order. Basic parameters like basin area, basin length, number and lengths of streams of each different order, basin perimeter, total basin length and bifurcation ratio were measured using GIS software. Stream frequency, drainage density, drainage texture, Lemniscate ratio, form factor, elongation ration and circularity ratio were evaluated using the mathematical equations elaborated by Strahler [8] [9] [11].

Significant geomorphometric parameters such as relative relief, basin relief and dissection index have been quantified and calculated from the Digital Elevation Model (DEM). The hypsometric curve, hypsometric inte- 


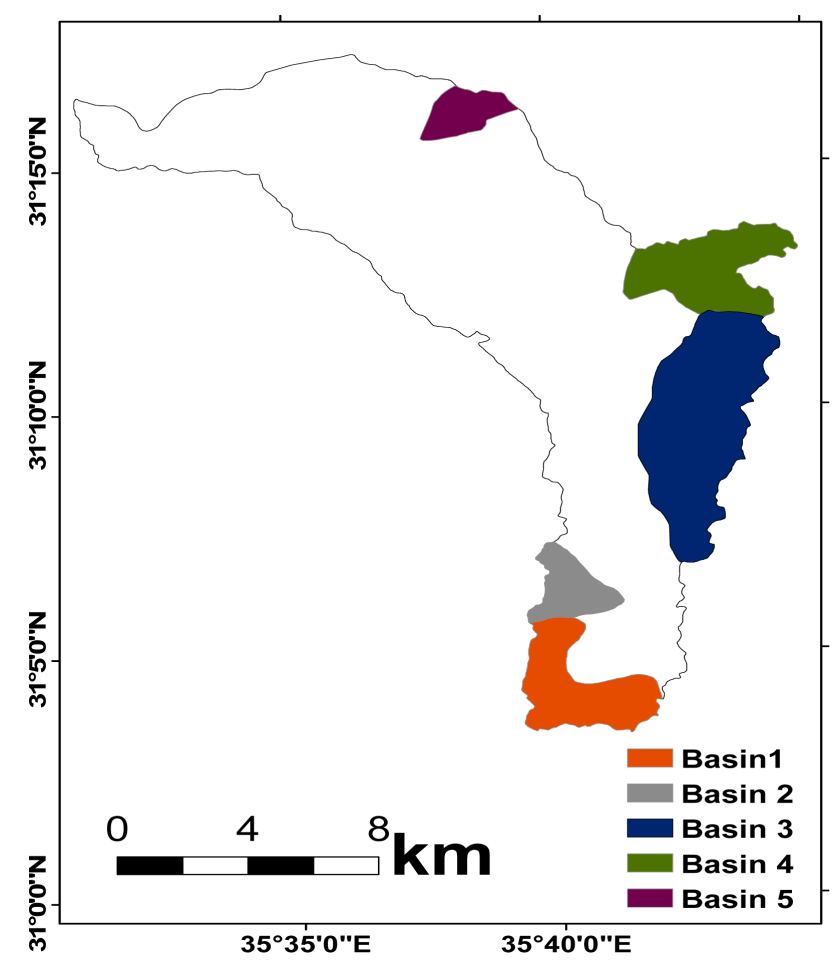

Figure 2. Selected sub-basins of W. Kerak catchment.

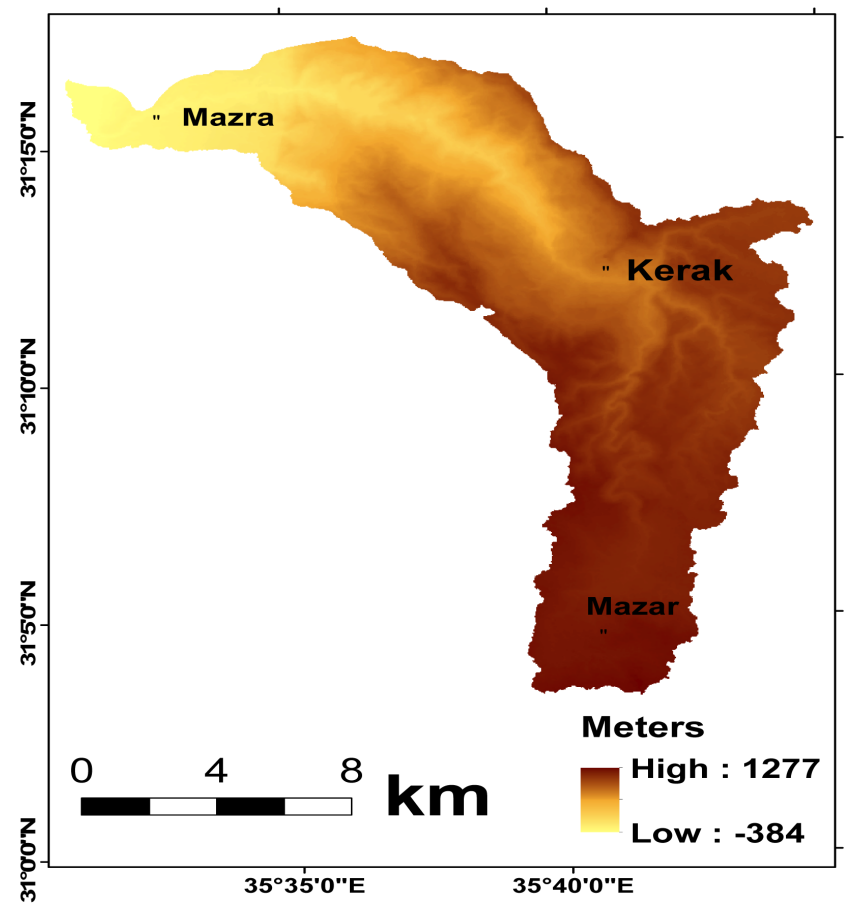

Figure 3. Digital elevation model of W. Kerak watershed.

gral and the clinogrphic curve for $\mathrm{W}$. Kerak were calculated and drawn manually using topographic maps of scale 1:50,000 [55]. The hypsometric curve (HC) is an area-elevation relationship curve that plots normalized elevation against normalized area of a watershed [8]-[11] and classifies the watersheds into several levels of geomorphic maturity as influenced by various agents, such as climate, lithology and tectonics. The hypsometric 
integral (HI) is normally calculated from the area under hypsometric curve and is expressed as a percentage. It represents the volume of the original basin that remains uneroded [15].

Stream-entrance angle between a tributary and the higher-order stream which it enters was measured and assessed according to Horton [7]. It is characteristic that mean values of entrance angle increase as the order of receiving stream increases (i.e. as the difference between Sc and Sg increases), and it is inversely related to relief (for a given orders of junction), probably because high relief imparts especially high gradients to the receiving streams [1]. The clinographic curve which devised by Hanson-Low [56] was employed to demonstrate the average angle of slope of inter-contour areas. The curve is obtained by plotting the average gradient between successive contours. It reveals where marked breaks of slope occur. The methodology adopted for the computation of morphometric parameters is illustrated in Table 1.

\section{Results and Discussion}

\subsection{Morphometric Analysis}

Quantitative analysis of W. Kerak basin and five sub-basins was performed to assess the characteristics and properties of the drainage network. Twenty-two morphometric parameters which represent basic, linear, areal, shape, and relief aspects of the watershed were considered for analysis in order to characterize the catchment, and to improve our understanding of: tectonic activity, geomorphic history, erosional stage of landforms, rejuvenation phases and geomorphic processes operating across the watershed [7] [11]. The drainage pattern of the W. Kerak watershed clearly reflects the structure and lithology of the basin. It comprises mainly a trellis type, with sub-dendritic pattern recognized in the upper catchment. These patterns are indicative of prominent structural control in the lower and middle catchment, and lithological uniformity in the upper catchment. In the present investigation, stream ordering for the watershed and sub-watersheds has been ranked according to Strahler's technique of the hierarchical ranking system [8] [11]. Stream ordering of a drainage network represents a measure of the extent of stream branching within a watershed. Each length of stream is identified by its order (i.e. first-order, second-order, etc.). According to Horton's Law, a first-order stream is an un-branched tributary, and a second-order stream is a tributary formed by two or more first-order streams. A third-order stream is a tributary formed by two or more second-order streams and so on [6]. It is noticeable that the total length of the streams segment in W. Kerak is maximum in the first-order streams and decreases as the stream order increases. This change in stream may indicate the flowing of streams from high altitude to moderate and steep slopes. It is postulated that this information of stream order number is useful in relating the size of its contributing basin and is based on the hierarchical ranking of streams [48].

\subsubsection{Basic Parameters}

The computed morphometric parameters are summarized in Table 2 \& Table 3 and will be discussed accordingly. Based on drainage order, the watershed is classified as a fifth-order basin (Figure 4) with an area of $190.9 \mathrm{~km}^{2}$ length of $33.95 \mathrm{~km}$, and perimeter of $99.49 \mathrm{~km}$. The total number of streams $\left(\mathrm{N}_{\mathrm{u}}\right)$ is 762 , and the first-order streams account for $81 \%$ of the total number of streams in the catchment. The details of stream characteristics for W. Kerak confirms Horton's first law [7], the "law of stream numbers", which states that the number of steams of different orders in a given drainage basin tends to closely approximate an inverse geometric ratio. This inverse geometric relationship is shown graphically in the form of a straight line when $\log$ values $\mathrm{N}_{\mathrm{u}}$ are plotted on an ordinary graph (Figure 5(a)). It is apparent that the total number of streams gradually decreases as the stream order increases (Table 2). The variation existing in the stream order is attributed largely to structural and morphological characteristics of the watershed. The total number and total length of stream order change according to the size of the sub-basins. However, the total number of streams at various orders, and their lengths from mouth to drainage divide for $\mathrm{W}$. Kerak (including the sub-basins) were derived from the DEM and measured with the help of Arc GIS software. Their number and lengths are higher and more precise compared with those measured manually from topographic maps of scale 1:50,000 [55].

\subsubsection{Linear Parameters}

1) The Stream Length $\left(L_{u}\right)$ has been calculated according to the law proposed by Horton [7]. It is stated that stream length is an indicator of chronological development of stream segments and tectonic disturbances. Generally, the higher the order, the longer the length of stream in nature. The total stream length is $488.536 \mathrm{~km}$, and the 
Table 1. Methodology adopted for computation of morphometric parameters.

\begin{tabular}{|c|c|c|}
\hline Morphometric Parameters & Formula/Definition & References \\
\hline Area (A) & Plan area of the watershed $\left(\mathrm{km}^{2}\right)$ GIS software analysis & [7] \\
\hline Basin perimeter $(\mathrm{P})$ & Perimeter of the watershed $(\mathrm{km})$ GIS software analysis & [7] \\
\hline Stream order & Hierarchical rank & [10] \\
\hline Basin length $\left(\mathrm{L}_{\mathrm{b}}\right)$ & Length of the stream $(\mathrm{km})$ GIS software analysis & [7] \\
\hline Mean stream length $\left(\mathrm{L}_{\mathrm{sm}}\right)$ & $\begin{array}{l}\mathrm{L}_{\mathrm{sm}}=\mathrm{L}_{\mathrm{u}} / \mathrm{N}_{\mathrm{u}}(\mathrm{km}) \text { where, } \\
\mathrm{L}_{\mathrm{sm}}=\text { mean stream length } \\
\mathrm{L}_{\mathrm{u}}=\text { total stream length of all orders } \\
\mathrm{N}_{\mathrm{u}}=\text { total no. of stream segments of order " } \mathrm{u} \text { " } \\
\mathrm{GIS} \text { software analysis }\end{array}$ & [11] \\
\hline Stream length ratio $\left(\mathrm{R}_{\mathrm{L}}\right)$ & $\begin{array}{l}\mathrm{R}_{\mathrm{L}}=\mathrm{L}_{\mathrm{u}} / \mathrm{L}_{\mathrm{u}}-1 \text {, where } \mathrm{L}_{\mathrm{u}}-1=\text { the total stream length } \\
\text { of its next lower order }\end{array}$ & [7] \\
\hline Bifurcation ratio $\left(\mathrm{R}_{\mathrm{b}}\right)$ & $\begin{array}{l}\mathrm{R}_{\mathrm{b}}=\mathrm{N}_{\mathrm{u}} / \mathrm{N}_{\mathrm{u}}+1 \text {, where, } \\
\mathrm{N}_{\mathrm{u}}+1 \text { = no. of segments of the next higher order }\end{array}$ & [14] \\
\hline Mean bifurcation ratio $\left(\mathrm{R}_{\mathrm{bm}}\right)$ & $\mathrm{R}_{\mathrm{bm}}=$ average of bifurcation ratio of all orders & {$[10]$} \\
\hline Drainage density $\left(D_{d}\right)$ & $\begin{array}{l}\mathrm{D}_{\mathrm{d}}=\mathrm{L}_{\mathrm{u}} / \mathrm{A} \text {, where, } \\
\mathrm{L}_{\mathrm{u}}=\text { total stream length of all orders }(\mathrm{km}) \\
\mathrm{A}=\text { area of the watershed }\left(\mathrm{km}^{2}\right)\end{array}$ & [7] \\
\hline Relief ratio $\left(\mathrm{R}_{\mathrm{r}}\right)$ & $\begin{array}{l}\mathrm{R}_{\mathrm{r}}=\mathrm{H} / \mathrm{L}_{\mathrm{b}} \text {, where, } \\
\mathrm{H}=\text { total relief } \\
\mathrm{L}_{\mathrm{b}}=\text { basin length } \\
\text { GIS software analysis using DEM }\end{array}$ & [57] \\
\hline Stream frequency $\left(\mathrm{F}_{\mathrm{s}}\right)$ & $\begin{array}{l}\mathrm{F}_{\mathrm{s}}=\mathrm{N}_{\mathrm{u}} / \mathrm{A}, \text { where, } \\
\mathrm{N}_{\mathrm{u}}=\text { total no. of streams of all orders } \\
\mathrm{A}=\text { area of the basin }\left(\mathrm{km}^{2}\right)\end{array}$ & [6] \\
\hline Form factor $\left(\mathrm{R}_{\mathrm{f}}\right)$ & $\begin{array}{l}\mathrm{R}_{\mathrm{f}}=\mathrm{A} / \mathrm{L}_{\mathrm{b}}^{2} \text {, where } \\
\mathrm{A}=\text { area of the basin }\left(\mathrm{km}^{2}\right) \\
\mathrm{L}_{\mathrm{b}}^{2}=\text { square of the basin length }\end{array}$ & [7] \\
\hline $\begin{array}{l}\text { Basin relief }\left(\mathrm{B}_{\mathrm{h}}\right) \\
\text { or } \\
\text { Total relief }(\mathrm{H})\end{array}$ & $\begin{array}{l}\mathrm{B}_{\mathrm{h}}=\mathrm{h}-\mathrm{h}_{1} \text {, where, } \\
\mathrm{h}=\text { maximum height }(\mathrm{m}) \\
\mathrm{h}_{1}=\text { minimum height }(\mathrm{m}) \\
\text { GIS software analysis using DEM }\end{array}$ & [58] \\
\hline Elongation ratio $\left(\mathrm{R}_{\mathrm{e}}\right)$ & $\begin{array}{l}\mathrm{R}_{\mathrm{e}}=1.128 \sqrt{\mathrm{A}} / \mathrm{L}_{\mathrm{b}} \text {, where, } \\
\mathrm{A}=\text { area of the basin }\left(\mathrm{km}^{2}\right) \\
\mathrm{L}_{\mathrm{b}}=\text { basin length }\end{array}$ & {$[14]$} \\
\hline Circularity ratio $\left(\mathrm{R}_{\mathrm{c}}\right)$ & $\begin{array}{l}\mathrm{R}_{\mathrm{c}}=4 \times \pi \times \mathrm{A} / \mathrm{P}^{2} \text { where, } \\
\pi=3.14 \\
\mathrm{~A}=\text { area of the bain }\left(\mathrm{km}^{2}\right) \\
\mathrm{P}=\text { perimeter }(\mathrm{km})\end{array}$ & [11] [13] \\
\hline Lemniscate ratio (k) & $\begin{array}{l}\mathrm{k}=\mathrm{L}_{\mathrm{b}}{ }^{2} / 4 \mathrm{~A} \text { where, } \\
\mathrm{L}_{\mathrm{b}}=\text { basin length }(\mathrm{km}) \\
\mathrm{A}=\text { area of basin }\left(\mathrm{km}^{2}\right)\end{array}$ & [18] [59] \\
\hline Drainage texture $\left(D_{t}\right)$ & $\begin{array}{l}D_{t}=N_{u} / P, \text { where } \\
N_{u}=\text { total no. of stream segments of order " } u \text { " } \\
P=\text { perimeter of the watershed }(\mathrm{km})\end{array}$ & [12] \\
\hline Dissection index $\left(D_{\mathrm{is}}\right)$ & $\begin{array}{l}\mathrm{D}_{\mathrm{is}}=\mathrm{B}_{\mathrm{h}} / \mathrm{R}_{\mathrm{a}}, \text { where, } \\
\mathrm{R}_{\mathrm{a}}=\text { absolute relief } \\
\mathrm{B}_{\mathrm{h}}=\text { basin relief or total relief }\end{array}$ & {$[60]$} \\
\hline Ruggedness number $\left(\mathrm{R}_{\mathrm{n}}\right)$ & $\begin{array}{l}\mathrm{R}_{\mathrm{n}}=\mathrm{D}_{\mathrm{d}} *\left(\mathrm{~B}_{\mathrm{h}} / 1000\right), \text { where, } \\
\mathrm{B}_{\mathrm{h}}=\text { basin relief } \\
\mathrm{D}_{\mathrm{d}}=\text { drainage density }\end{array}$ & [11] \\
\hline Hypsonetric integral (HI) & $\begin{array}{l}\mathrm{HI}=(\mathrm{H}-\mathrm{h}) /(\mathrm{H}-\mathrm{h}), \text { where, } \\
\mathrm{H}=\text { the weighted mean elevation } \\
\mathrm{H}=\text { maximum elevation } \\
\mathrm{h}=\text { minimum elevation }\end{array}$ & [8] [10] [11] \\
\hline
\end{tabular}




\section{Continued}

Hypsometric curve (HC)

Stream-entrance angle $\left(\mathrm{Z}_{c}\right)$

Clinographic curve (Cc)
HC obtained by plotting the proportion of the total height $(\mathrm{h} / \mathrm{H})$ against the proportion of the total area $(\mathrm{a} / \mathrm{A})$ of the

basin, where $\mathrm{H}$ is the total relative height, $\mathrm{A}$ is the total area of the basin and $\mathrm{a}$ is the area of the basin above a given line of elevation $h$.

$$
\begin{aligned}
& \cos Z_{c}=\frac{\tan S_{c}}{\tan S_{g}} \\
& \cos Z_{c}=\frac{\tan \gamma}{\tan \theta} .
\end{aligned}
$$

where $\left(Z_{c}\right)$ the angle entrance between a tributary developed in a valley-side slope (of $\theta^{\circ}$ ) and joining a large stream of lower slope $\left(\gamma^{\circ}\right) . \mathrm{S}_{\mathrm{c}}$ : is the channel slope of the parent stream Sg: is the ground slope. It is assumed to be the same as the slope of the tributary stream.

Cc is based on the formula

Tan $\theta=$ Cin/Swc

where, Cin: contour interval,

Swc: average width between two successive contours

calculated as $\mathrm{Ac} /\{\mathrm{L} 1+\mathrm{L} 2) / 2\}$,

Ac: total areas between successive contours

L1 + L2 are the lengths of two successive contours

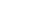

Table 2. Morphometric parameters of W. Kerak watershed*.

\begin{tabular}{|c|c|c|c|c|c|c|c|c|c|c|c|c|c|c|}
\hline \multirow{3}{*}{ Parameters } & \multirow{3}{*}{$\mathrm{A}\left(\mathrm{km}^{2}\right)$} & \multirow{3}{*}{$\mathrm{L}_{\mathrm{b}}(\mathrm{km})$} & \multirow{3}{*}{$\mathrm{P}(\mathrm{km})$} & \multirow{3}{*}{$\begin{array}{c}\text { Stream } \\
\text { order }\end{array}$} & \multirow{3}{*}{$\mathrm{L}_{\mathrm{u}}(\mathrm{km})$} & \multirow{3}{*}{$\begin{array}{c}\mathrm{L}_{\mathrm{sm}} \\
(\mathrm{Km})\end{array}$} & \multicolumn{4}{|c|}{$\mathrm{R}_{\mathrm{L}}$} & \multicolumn{4}{|c|}{$\mathrm{R}_{\mathrm{b}}$} \\
\hline & & & & & & & \multicolumn{4}{|c|}{ Order } & \multicolumn{4}{|c|}{ Order } \\
\hline & & & & & & & II & III & IV & V & I & II & III & IV \\
\hline Wadi Kerak & 190.90 & 33.95 & 99.49 & 5 & 488.53 & 0.641 & 0.455 & 0.437 & 0.406 & 2.057 & 5.6 & 3.7 & 6 & 5 \\
\hline
\end{tabular}

(a)

(b)

\begin{tabular}{cccccccccccccccc}
$\mathrm{R}_{\mathrm{bm}}$ & $\mathrm{D}_{\mathrm{d}}$ & $\mathrm{R}_{\mathrm{r}}$ & $\mathrm{F}_{\mathrm{s}}$ & $\mathrm{R}_{\mathrm{f}}$ & $\mathrm{B}_{\mathrm{h}}$ & $\mathrm{R}_{\mathrm{e}}$ & $\mathrm{R}_{\mathrm{c}}$ & $\mathrm{R}_{\mathrm{n}}$ & $\mathrm{K}$ & $\mathrm{T}$ & $\mathrm{D}_{\mathrm{i}}$ \\
\hline 5.302 & 2.559 & $48.924 \mathrm{~m} / \mathrm{km}$ & 3.991 & 0.165 & 1661 & 0.459 & 0.241 & 4.24 & 1.509 & 10.187 & 1.300 \\
\hline
\end{tabular}

*Area (A), Basin length (L), Basin perimeter $(\mathrm{P})$, Stream length $\left(\mathrm{L}_{\mathrm{u}}\right)$, Mean stream length $\left(\mathrm{L}_{\mathrm{sm}}\right)$, Stream length ratio ( $\left.\mathrm{R}_{\mathrm{L}}\right)$, Bifurcation ratio $\left.\mathrm{R}_{\mathrm{b}}\right)$, Mean bifurcation ratio $\left(R_{b m}\right)$, Drainage density $\left(D_{d}\right)$, Relief ratio $\left(R_{r}\right)$, Stream frequency $\left(F_{s}\right)$, Form factor $\left(R_{f}\right)$, Basin relief $\left(B_{h}\right)$, Elongation ratio $\left(R_{e}\right)$, Circularity ratio $\left(\mathrm{R}_{\mathrm{c}}\right)$, Ruggedness number $\left(\mathrm{R}_{\mathrm{n}}\right)$, Lemniscate ratio $(\mathrm{k})$, Drainage Texture $(\mathrm{T})$, Dissection Index (Di), Hypsometric Integral (HI), Hypsometric Curve (HC).

first-order streams constitute $52.1 \%$ of the total stream length. The stream length characteristics of W. Kerak verify Horton's second law [7], the "law of stream length”, which affirms that the average length of steams of each of the different orders in a drainage basin tends closely to approximate a direct geometric ratio. This geometric linear relationship is shown graphically when log values of these parameters are plotted on an ordinary graph (Figure 5(b)). Most drainage networks show a linear relationship with a small deviation from a straight line. Mean stream length $\left(\mathrm{L}_{\mathrm{sm}}\right)$ is a dimensional property revealing the characteristic size of components of a drainage network and its contributing basin surfaces [11]. It is calculated by dividing the total stream length of order (u) by the number of segments $\mathrm{N}_{\mathrm{u}}$ of that order. It is obvious that the $\mathrm{L}_{\mathrm{sm}}$ values for the W. Kerak watershed vary from 0.42 to 6.94 , while $\mathrm{L}_{\mathrm{sm}}$ values for the five sub-basins vary from 0.34 to $1.37 ; 0.48$ to 0.93 ; 0.33 ; to 2.6 and 0.59 to 1.9 respectively. It is clear that $\mathrm{L}_{\mathrm{sm}}$ of any given order is greater than that of the lower order and less than that of its next higher order in both W. Kerak and its sub-basins. Stream length ration $\left(R_{L}\right)$ is the ratio between the mean length of streams of a given order to the mean length of streams in the next lower order. $R_{L}$ is considered an important factor in relation both to drainage composition and geomorphic development of drainage basins [7]. A variation exists in $\mathrm{R}_{\mathrm{L}}$ values between the streams of different order for the W. Kerak catchment and its five sub-basins. This variation might be attributed to morphological changes in slope and relief along the Ke- 
Table 3. Morphometric parameters of W. Kerak sub-basins.

(a)

\begin{tabular}{|c|c|c|c|c|c|c|c|c|c|c|c|c|}
\hline \multirow{3}{*}{ Parameters } & \multirow{3}{*}{$\mathrm{A}\left(\mathrm{km}^{2}\right)$} & \multirow{3}{*}{$\mathrm{L}_{\mathrm{b}}(\mathrm{km})$} & \multirow{3}{*}{$\mathrm{P}(\mathrm{km})$} & \multirow{3}{*}{$\begin{array}{c}\text { Stream } \\
\text { Order }\end{array}$} & \multirow{3}{*}{$\mathrm{L}_{\mathrm{u}}(\mathrm{km})$} & \multirow{3}{*}{$\mathrm{L}_{\mathrm{sm}}(\mathrm{km})$} & \multirow{2}{*}{\multicolumn{3}{|c|}{$\begin{array}{c}\mathrm{R}_{\mathrm{L}} \\
\text { Order }\end{array}$}} & \multirow{2}{*}{\multicolumn{3}{|c|}{$\begin{array}{c}\mathrm{R}_{\mathrm{b}} \\
\text { Order }\end{array}$}} \\
\hline & & & & & & & & & & & & \\
\hline & & & & & & & II & III & IV & I & II & III \\
\hline Sub-basin 1 & 10.190 & 6.170 & 18.270 & 4 & 27.480 & 0.490 & 0.327 & 0.876 & 1.080 & 4.2 & 3.33 & 3 \\
\hline Sub-basin 2 & 4.400 & 3.130 & 10.110 & 4 & 11.695 & 0.584 & 0.535 & 0.556 & 0.137 & 3.25 & 2 & 2 \\
\hline Sub-basin 3 & 23.690 & 8.920 & 24.470 & 4 & 51.930 & 0.596 & 0.449 & 1.144 & 0.181 & 4.928 & 4.666 & 3 \\
\hline Sub-basin 4 & 11.450 & 5.370 & 18.910 & 4 & 24.960 & 0.520 & 0.316 & 1.260 & 0.567 & 6.5 & 3 & 2 \\
\hline Sub-basin 5 & 3.610 & 3.080 & 8.250 & 3 & 10.050 & 0.773 & 0.637 & 0.076 & $* *$ & 5 & 2 & ** \\
\hline
\end{tabular}

(b)

\begin{tabular}{ccccccccccccc}
\hline $\mathrm{R}_{\mathrm{bm}}$ & $\mathrm{D}_{\mathrm{d}}$ & $\mathrm{R}_{\mathrm{r}}$ & $\mathrm{R}_{\mathrm{n}}$ & $\mathrm{F}_{\mathrm{s}}$ & $\mathrm{R}_{\mathrm{f}}$ & $\mathrm{B}_{\mathrm{h}}$ & $\mathrm{R}_{\mathrm{e}}$ & $\mathrm{R}_{\mathrm{c}}$ & $\mathrm{k}$ & $\mathrm{T}$ & $\mathrm{D}_{\mathrm{i}}$ \\
\hline 3.966 & 2.696 & $22.366 \mathrm{~m} / \mathrm{km}$ & 0.051 & 5.495 & 0.267 & 138 & 0.583 & 0.376 & 0.933 & 14.814 & 0.108 \\
2.817 & 2.657 & $38.658 \mathrm{~m} / \mathrm{km}$ & 0.321 & 4.545 & 0.449 & 121 & 0.755 & 0.540 & 0.556 & 12.076 & 0.090 \\
4.811 & 2.192 & $39.013 \mathrm{~m} / \mathrm{km}$ & 0.763 & 3.672 & 0.297 & 348 & 0.615 & 0.489 & 0.839 & 8.049 & 0.299 \\
5.758 & 2.179 & $76.908 \mathrm{~m} / \mathrm{km}$ & 0.90 & 4.192 & 0.397 & 413 & 0.710 & 0.427 & 0.630 & 9.134 & 0.381 \\
4.4 & 2.783 & $291.233 \mathrm{~m} / \mathrm{km}$ & 2.496 & 3.601 & 0.380 & 897 & 0.695 & 0.665 & 0.656 & 10.021 & 0.969 \\
\hline
\end{tabular}

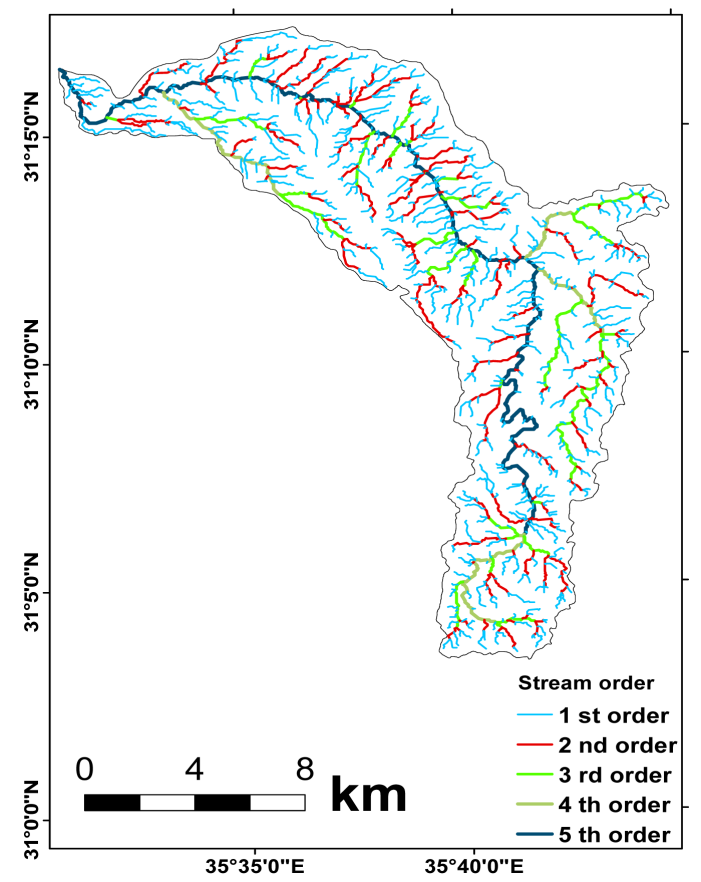

Figure 4. Drainage order for W. Kerak watershed.

rak graben initiated along the Al Keral-Al-fiha fault system, and the youth-age stage of geomorphic development of the watershed.

2) The Bifurcation Ratio $\left(R_{b}\right)$ is the ration of the number of streams of a given order to the number of streams of the next higher order [14]. The bifurcation ratio is designated by Horton [7] as an index of relief and dissection. It value is about 2 for flat or rolling drainage basins, and up to 3 or 4 for mountainous or highly dissected drainage basins. Characteristically, $\mathrm{R}_{\mathrm{b}}$ values range between 3.66 and 6 for watersheds in which the geologic 


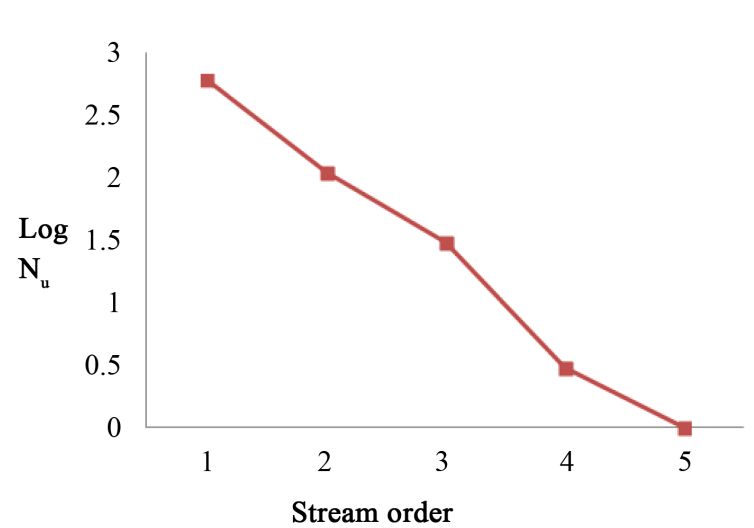

(a)

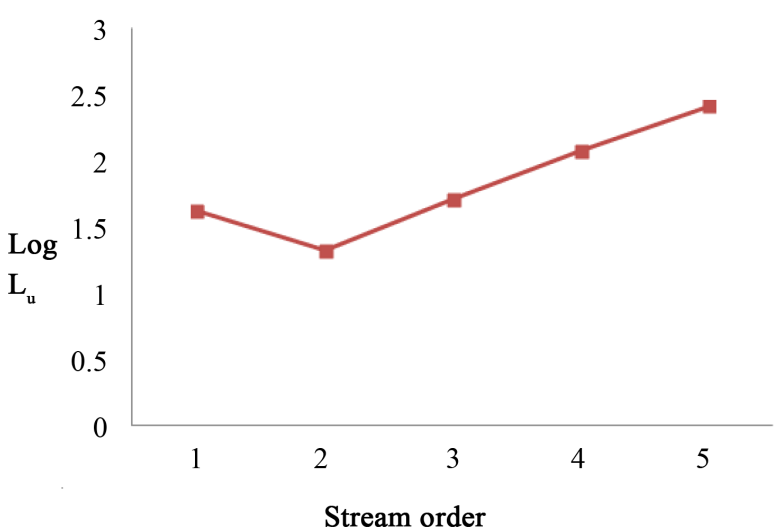

(b)

Figure 5. Horton’s first law (a) and Horton’s second law (b) using W. Kerak watershed.

structures distort the drainage pattern. By contrast, lower values of $\mathrm{R}_{\mathrm{b}}$ are characteristics of structurally less disturbed watersheds without any distortion in drainage pattern [11]. Abnormally high bifurcation ratios might be expected in regions of steeply dipping rock strata, where narrow strike valleys are confined between hogback ridges. The mean bifurcation ratio $\left(\mathrm{R}_{\mathrm{bm}}\right)$ of the $\mathrm{W}$. Kerak catchment is 5.30 , while the $\mathrm{R}_{\mathrm{bm}}$ values for the upper catchment rises to 5.76 (basin 4, east of Kerak city). Such high figures indicate that drainage development in the main watershed including the sub-basins is influenced crucially by structural disturbances represented by the Al-Kerak-Al-fiha fault system, tectonic activity, rejuvenation phases, and, the existence of Ed Dhira flexure at the lower part of the catchment. Here, prominent hogback ridges with steeply dipping strata $\left(\approx 75^{\circ}\right)$ were formed close to the rift, east of Ghor Mazra.

\subsubsection{Areal Parameters}

1) Drainage Density $\left(D_{d}\right)$ is defined as the closeness of spacing of channels. It is a measure of the total length of streams in a catchment per unit area, and it is a measure of landscape dissection and runoff potential of the basin. Thus, $D_{d}$ has units of reciprocal of length $(1 / L)$. A high value of $D_{d}$ would indicate a relatively high density of steams and thus, a rapid stream response. High drainage density of an area is indicative of high run-off, and consequently a low infiltration rate, whereas, low drainage density of an area implies low run-off and high infiltration [62]. Slope steepness and relative relief are the main morphological factors controlling drainage density. Strahler [11] concluded that low $\mathrm{D}_{\mathrm{d}}$ occurs where basin relief is high. Other important factors determining $D_{d}$ are infiltration-capacity of the soil, and initial resistance of the terrain towards erosion. Intermittent and ephemeral streams which carry flood water should be included in calculating drainage density. The poorly drained basins have a drainage density of 2.74, while the well-drained one has a density of 0.73 , or one fourth as great [7]. The $D_{d}$ value for the $W$. Kerak catchment is 2.6, while, $D_{d}$ values for the sub-basins range between 2.2 (sub-basin 3) and 2.8 (sub-basin 5). Such values are classified as coarse drainage density according to Smith [12]. These figures also are indicative of highly dissected steep terrain with impervious underlying rocks, especially the nodular limestone or the marly-clay unit, and the Echinoidal or the limestone-marl unit. Both are exposed mainly along the middle catchment where a series of springs exist.

2) Drainage Texture (T) is an expression of the relative spacing of drainage lines in a fluvially dissected terrain. It is defined as the total number of stream segments of all orders per perimeter of that area [7]. $\mathrm{T}$ is considered one of the main concepts in drainage basin geomorphology. It depends on several intrinsic physical factors such as climate, rainfall, vegetation, soil, lithology, infiltration-capacity, relief, and stage of watershed development. According to Smith [12], drainage texture is classified into four categories: coarse $(\mathrm{T} \leq 4)$, moderate $(\mathrm{T}=$ 4 - 10), fine ( $\mathrm{T}$ value is above 10), and ultra-fine or badlands topography ( $\mathrm{T}$ value is $>15$ ). It is obvious from such classification, that the drainage texture of the W. Kerak catchment $(\mathrm{T}=10)$ is moderate, whereas sub-basins $1(\mathrm{~T}=14.8)$ and $2(\mathrm{~T}=12)$ exhibit a fine drainage texture. High drainage texture values indicate the presence of soft rock with low resistance against erosion.

3) Stream Frequency $\left(F_{s}\right)$ represents the ratio of the total number of streams $\left(N_{u}\right)$ in a basin to the basin area (A), and is defined as the number of streams per unit of area [7]. The value of stream frequency ranges from 
3.91 to 9.99 . The $\mathrm{F}_{\mathrm{s}}$ value depends mainly on the lithology of the basin and, reflects the texture of the drainage network. Statistically, the $F_{s}$ value is positively correlated with $D_{d}$ values of the watershed, which means that the increase in stream population is connected to that of drainage density [63]. The values of $D_{d}$ and $F_{s}$ for small and large drainage basins are not directly comparable because they usually vary with the size of the drainage area. High stream frequency means more percolation with respect to drainage density, and hence more groundwater potential [64]. The $\mathrm{F}_{\mathrm{s}}$ value for $\mathrm{W}$. Kerak watershed is 3.98, and for sub-basins 1 - 5 are; 5.5, 4.5, 3.7, 4.2, and 3.6 respectively. $F_{s}$ values are relatively low for both $\mathrm{W}$. Kerak and the sub-basins which indicate that more surface water infiltrates down to subsurface strata; thus, groundwater potential is relatively high, with 35 active springs issuing along the middle course of the wadi [65].

\subsubsection{Shape Parameters}

1) Elongation Ratio $\left(R_{e}\right)$ is defined as the ratio between the diameter of the circle of the area as represented by the drainage basin to the maximum basin length [14]. Strahler [11], stated that the values of $R_{e}$ generally vary between 0.6 to 1.0 over a wide range of climate and geological conditions. Values close to 1.0 are typical of regions with very low relief, whereas values in the range of $0.6-0.8$ are normally characteristic of watersheds with high relief and steep slopes. The low values of $R_{e}$ indicate that a particular mini-watershed is more elongated than others. Where the $R_{e}$ approaches 1.0, the shape of the drainage basin approaches a circle [14]. It has been reported that a circular basin is more efficient in runoff than is an elongated one [66]. Based on $R_{e}$ values, watersheds were grouped into five categories, i.e. circular (0.9 - 1.0); oval (0.8 - 0.9), less elongated (0.7 - 0.8); elongated $(0.5$ - 0.7$)$, and more elongated $(<0.5)$. The elongation ratio for W. Kerak is 0.46 , while the values related to the five sub-basins are: $0.583,0.755,0.615,0.710,0.695$ respectively. All these values are indicative of elongated shape, and associated with high relief and steep slopes. They also imply that the hydrograph of these basin and sub-basins might be smoother (i.e. the crest segment of the hydrograph will be flatter and the slope of the rising and recession limbs will be low) [19].

2) Circularity Ratio $\left(R_{c}\right)$ refers to the ratio of basin area $(A)$ to the area of circle having the same circumference as the perimeter of the basin [13]. It is controlled by the length and frequency of the streams, geological structures, land use, land cover, climate, relief and slope steepness of the watershed. Drainage basins with a range of circularity ratios of 0.4 to 0.5 , were described by Miller [13], indicating they are they are strongly elongated, highly permeable, with homogeneous geological materials. Low, medium and high values of $\mathrm{R}_{\mathrm{c}}$ indicate the young, mature, and old stage of the geomorphic cycle of the watershed [63]. The $\mathrm{R}_{\mathrm{c}}$ value of $\mathrm{W}$. Kerak watershed is 0.24 which denotes that the catchment is at a youth stage of geomorphic development, while the circularity ratios of the sub-basins vary from 0.4 to around 5 , which confirms that they are elongated.

3) Form factor (Rf) is expressed as the ratio between the area of the basin and the square of the basin length [7]. Rf parameter has been developed to predict the intensity of a basin of a defined area. For a perfectly circular basin, the value of the form factor should be always less than 0.75 [5]. The smaller the value of $\operatorname{Rf}(<0.45)$, the more the basin will be elongated. Basins with high Rf experience high peak flows of shorter duration, whereas an elongated watershed with a low form factor, has a low peak flow of longer duration. The Rf value for W. Kerak is 0.17 , and the values range from 0.27 to 0.45 for the sub-basins, which indicates that the W. Kerak watershed is an elongated basin. Thus, low peak flows of long duration are expected [63].

\subsubsection{Relief Parameters}

1) Basin Relief $\left(B_{h}\right)$ or "total relief" of the basin, is defined as the difference in elevation between the highest and lowest points on the basin [14]. Generally, relief measures are indicative of the potential energy of a drainage system present by virtue of elevation above a given datum [11]. Basin relief is an essential factor in understanding the denudational characteristics of the watershed, landforms and drainage networks development, overland flow, and through-flow and erosional properties of the terrain. The total relief of W. Kerak watershed is $1661 \mathrm{~m}$. Such a high value indicates a high potential erosional energy of the drainage system. Due to the sinking base level of the Ghor and the Dead Sea, and tectonic activity, W. Kerak entailed rapid incision during its geomorphic history, thus, giving, rise to the present rough terrain. Landslides and soil erosion are prominent active geomorphic processes across the watershed.

2) Relief Ratio $\left(R_{r}\right)$ is the ration between the total relief (or basin relief $B_{h}$ ) of a basin and the longest basin length parallel to the principal drainage line [14]. This relief ratio is dimensionless height-length ratio equal to the tangent of the angle formed by two planes intersecting at the mouth of the basin, one representing the hori- 
zontal, the other gassing through the highest point of the basin. Relief ratio allows comparison of the relative relief of any basin regardless of differences in scale of topography [14]. The $\mathrm{R}_{\mathrm{r}}$ value of the W. Kerak basin is 0.05 , which shows that considerable steep slopes and high relief are present in the lower and middle catchment, while gentle/rolling slopes are characteristics of the upper catchment where remnants of erosion surfaces predominate.

3) Dissection Index (Di) is a parameter referring to the degree of dissection or vertical erosion, and the stage of landforms development in any given watershed [60]. Di is the ratio between the total relief (relative relief) and absolute relief of the basin which always varies between 0.0 (complete absence of dissection and hence the dominance of flat topography) and 1 for infrequent cases such as vertical cliff topography at the sea shore, or vertical escarpment of hill-slope. Extreme values of Di certainly exceed 1 in rift regions such as Jordan. Elevations below sea level are present. Thus, the relative relief for a given watershed is occasionally higher than maximum (absolute) relief for the watershed. The W. Kerak catchment in the present study (and other wadis/ rivers draining to the rift) is an example. Here, the total relief of the catchment is $1661 \mathrm{~m}$, while the absolute relief of the basin is about 1275 meters a.s.l. Therefore, the Di value is 1.3 which clearly indicates that the catchment is extremely dissected due to successive phases of rejuvenation, youth-age stage of geomorphic development. The watershed is also highly prone to soil erosion, repetitive landslide movements, and susceptible to an increased peak discharge. Based on Di values, it is appropriate to propose a classification for watersheds in terms of dissection. Accordingly, watersheds can be grouped into five categories: a) flat-undulating $(<0.1)$, b) rolling $(0.1-0.4)$, c) moderately dissected $(0.4-0.7)$, d) highly dissected $(0.7-1.0)$, e) extremely dissected $(>1.0)$.

4) Ruggedness Number $\left(R_{n}\right)$ is dimensionless parameter which represents the product of basin relief $\left(B_{h}\right)$ and drainage density $\left(D_{d}\right)$ [8] [11]. Extremely high values of ruggedness number occur when both variables are large, as exemplified by W. Kerak and other Jordan Rift watersheds. In this context, the slopes are not only steep but long as well. Observed values of ruggedness number range from low (i.e. 0.06) for smooth and subdued morphology to over 1.0 for sharp morphology, or extreme figures characterizing badlands topography. To achieve a wide range of $R_{n}$ values to represent watersheds with subdued and sharp morphology, the authors divided the product of basin relief $\left(\mathrm{B}_{\mathrm{h}}\right)$ and drainage density $\left(\mathrm{D}_{\mathrm{d}}\right)$ by a constant 1000 and applied that on a series of watershed in the rift region. The product was values ranging from $<0.1$ to $>4$ as the case of $W$. Kerak $\left(R_{n}=4.24\right)$, while the $R_{n}$ for the five sub-basins are: $0.051 ; 0.321 ; 0.763 ; 0.9 ; 2.496$ respectively. The lowest value of $R_{n}$ is for sub-basin 1 and the highest $R_{n}$ value is for sub-basin 5 . Sub-basin 1 is located in the upper catchment, while sub-basins 2 - 4 are located in the middle catchment, and sub-basin 5 is part of the lower catchment where sharp morphology is characteristic. Following that, it was possible to classify watersheds (at least for our region and based on $R_{n}$ values into five categories: $<0.1$ subdued morphology; 0.1 - 0.4 slight morphology; 0.4 - 0.7 moderate morphology; 0.7 - 1.0 sharp morphology; >1.0 extreme morphological expression including badlands topography. Watersheds having high $\mathrm{R}_{\mathrm{n}}$ values are characterized by dynamic geomorphic processes, long and steep slopes interrupted by sharp breaks of slope due to rejuvenation processes, high susceptibility to soil erosion and mass movement, and high response to an increase in peak discharge.

5) The Lemniscate Ratio (k) was elaborated by Chorely et al. [59] as a measure to describe how closely the actual drainage basin shape approaches the loop of a lemniscates. They concluded that for describing the drainage basin shape accurately, it is essential to determine the lemniscates shape which the basin most nearly approaches. The lemniscates ratios allow to distinguish regional variation of drainage basin shapes. Thus, it is considered a useful index to differentiate one morphometric region from another, and to express quantitatively the structural control over basin shape, as for example in the effect of varying angles of dip on the shapes of drainage basins developed on a cuesta dip slopes. The lemniscate $(\mathrm{k})$ value for the $\mathrm{W}$. Kerak watershed is 1.5 which shows that the watershed is mostly elongated in shape and flow for a longer duration, while the values of $\mathrm{k}$ for the sub-basins range between 0.556 (sub-basin 2) and 0.933 (sub-basin 1).

\subsubsection{Hypsometric and Clinographic Parameters}

To illustrate the geomorphic evolution, type of erosive processes and relative age of landforms of the W. Kerak watershed, along with the influence of internal and external forcing factors on the basin topography (i.e. tectonic, lithology and climate), the hypsographic curve (expressing how much land lies between two contour lines), the hypsometric curve (area-elevation analysis), and the hypsometric integral of the basin have been calculated and prepared [28]. Hypsometry means relative proportion of an area at different elevation within a watershed, thus, it 
represents the distribution of area with respect to altitude [8]. Differences in the shape of the hypsometric curve (HC), and the hypsometric integral (HI) value are attributed mainly to the degree of disequilibria in the balance of erosive and tectonic factors [8] [14] [67]. The hypsometric curve expresses the volume of rock mass in the watershed and the amount of erosion that has taken place in that watershed against the remaining mass. Therefore, the hypsometric integral is used as an estimator of the erosion status of a watershed [42] [67] [68]. Strahler compared and evaluated different shapes of hypsometric curves pertaining to different drainage basins, and classified the basins according to their stages of geomorphological evolution as: youth stage (convex upward curves, where $\mathrm{HI} \geq 0.60$ ) where the watershed is highly susceptible to erosion, equilibrium or mature stage (S-shaped hypsometric curve which is concave upward at high elevations and convex downwards at low elevations, where $0.30 \leq \mathrm{HI} \leq 0.60$ ), and peneplain (old) or monadnock stage (concave upward curve, where $\mathrm{HI} \leq 0.30$ ). Such classification also provides an indication of the erosion status of watersheds [69], and reflects the interaction between tectonics and erosion [70] as represented by W. Kerak [55].

1) The Hypsometric Curve of the W. Kerak watershed is a convex upward curve, and the hypsometric integral is 0.73 , indicating that $\mathrm{W}$. Kerak is in the youth-age stage of geomorphic evolution, and subjected to tectonic activities (Figure 6). Extensive degradation that took place during the Upper Miocene-Pliocene resulted in the Upper Miocene-Pliocene planation surface to the east of the uplifted scarp overlooking the Jordan Rift. The present surface exists in the upper catchment of the Wadi between Kerak city and Mazar town. By contrast, dissected and rugged terrain characterized the western part of the watershed. Regional down warping towards the east was associated with high dissection as a response to recurrent lowering of the base level towards which the drainage network was progressively cutting. The rejuvenated canyon during lower Pleistocene has partially destroyed this surface to the north of W. Kerak, and the pre-existing drainage system was also disturbed. The scattered isolated hills with its summit accordance could be interpreted as the remnants of the Upper Miocene-Pliocene surface [71]. W. Kerak and other major streams draining to the west were also beheaded, and Wadi Moujeb captured the truncated drainage part of W. Kerak [72]. Field observations demonstrate that the present dimension of the large gorge of the wadi is out of proportion when compared with its small and misfit watershed. The only explanation for this situation, is that W. Kerak was beheaded at one time due to tectonic activity and the associated uplifting, and was never able to recover its former drainage basin. The graben which W. Kerak follows, continues a few kilometers southeast of Kerak city in Faj el-Useiker [73], which is separated from the present catchment due to uplifting of the land block east of Kerak probably during lower Pleistocene tectonics. As a result, the upper part of the canyon has been blocked, while the lower course now forming the wadi, remained open towards the rift. Then, at a later stage Faj el-Useiker was captured by an active tributary of Wadi Moujeb. Continued degradation in the lower part of the basin (West of Kerak city) resulted in deep incision

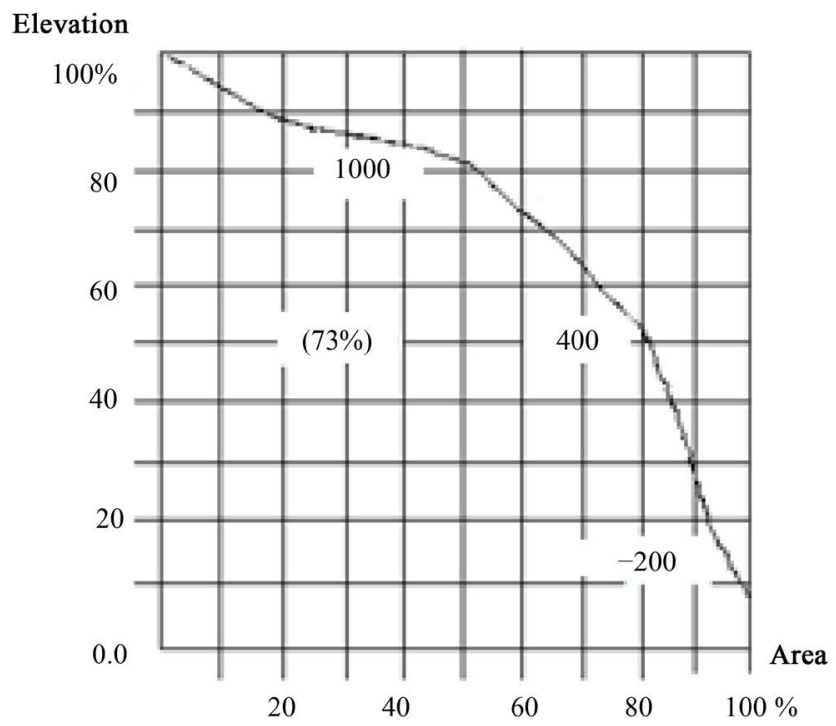

Figure 6. Hypsometric curve illustrates the youth-stage of development of W. Kerak. 
through underlying late Cambrian sandstones. Intrenched and ingrown meanders which characterized the upper reaches of W. Kerak, were inherited from former drainage which existed on the senile plateau surface before rejuvenation took place [74]. As the streams incised their courses following the lowering of base level, they managed to maintain the old bends, by adjusting to underlying structures; thus, spectacular incised meanders developed [55]. The canyon-like shape of W. Kerak penetrated $1700 \mathrm{~m}$ of rock strata ranging from late Cambrian sandstones to Eocene chalk, limestone and chert [52]. Such a huge range of downcutting indicates that W. Kerak and other streams draining to the rift have persisted at least since the Upper Miocene. In addition, the sinking floor of the Jordan Rift retained progressive downcutting and incision, but the grade (i.e. to start to form a floodplain) was never attained from early Pleistocene tectonics.

2) The Clinographic Curve seeks to demonstrate the average gradient between inter-contour areas in the form of an average profile, and reveal the breaks in slope and sudden changes in the relief of any area (i.e. watershed or region). In addition, it also represents the general trend of the surface, thus emphasizing uniform terrain such as plateau surface. Associated with longitudinal profile both provide a visual perception of the actual nature of terrain [16] [56] [75]. Different methods were elaborated to calculate the slope angle between two successive contours [8] [16]. The clinographic curve is drawn by plotting the ground slope against the contour height starting at the top of any area. The clinographic curve of the W. Kerak drainage basin is illustrated in (Figure 7). Generally, the shape of the clinographic curve is similar to the hypsographic curve (Figure 8). Both of them show four breaks at different elevations: 900 - $1000 \mathrm{~m}$ (a.s.l); $\approx 400 \mathrm{~m} ; 100 \mathrm{~m} ;-200 \mathrm{~m}$ (b.s.l). The most promi-

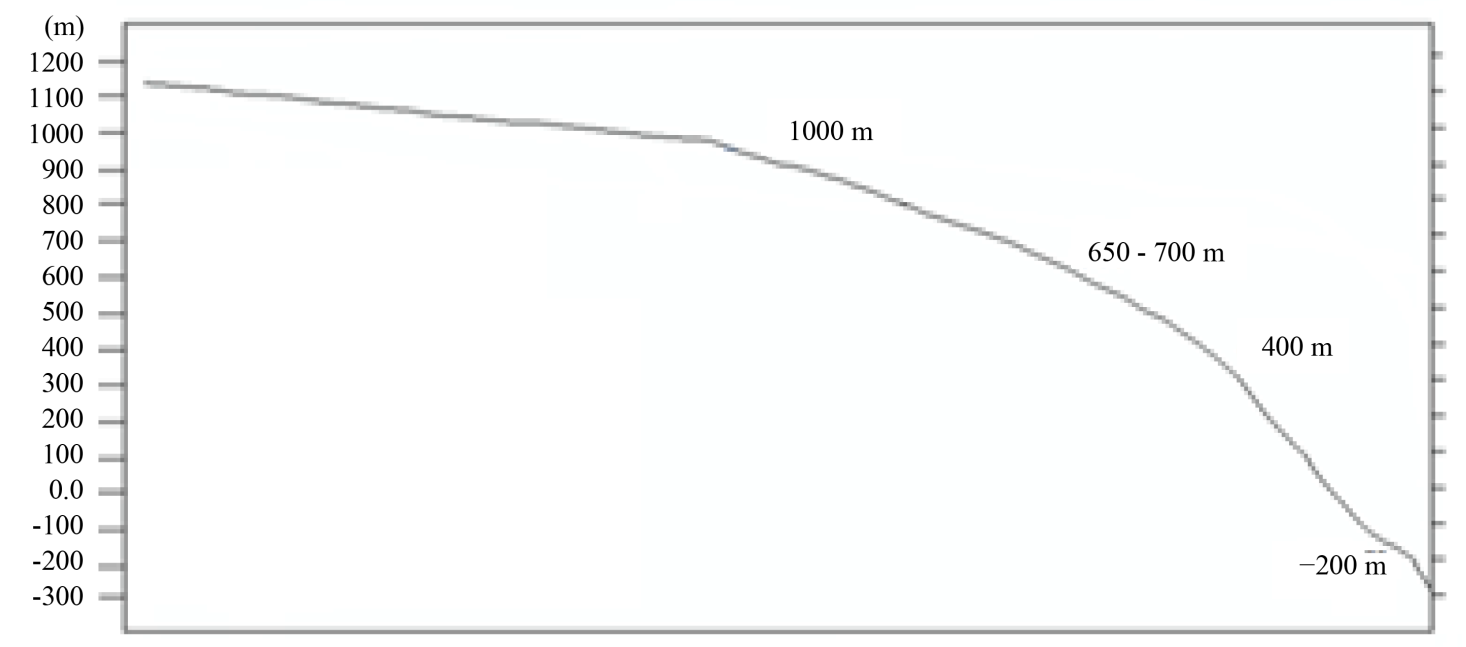

Figure 7. Clinographic curve illustrating major breaks across W. Kerak watershed.

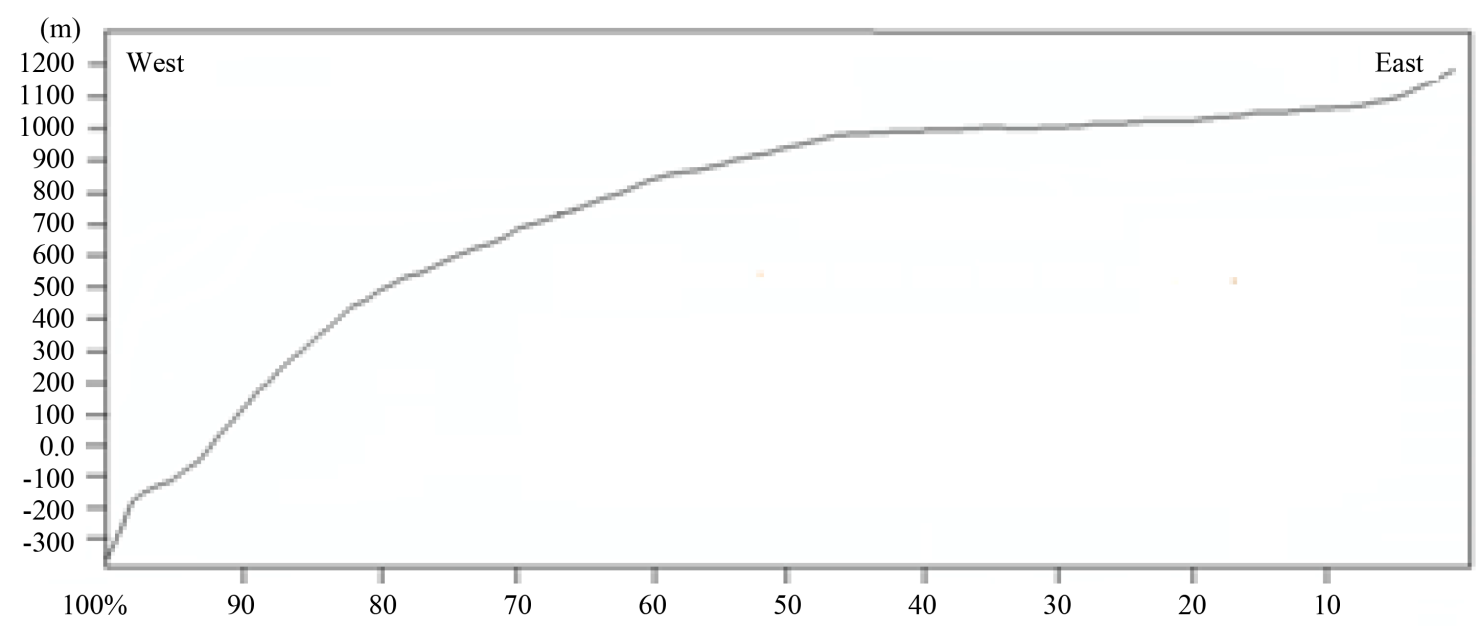

Figure 8. Hypsographic curve showing major breaks across W. Kerak catchment. 
nent break of slope is that which coincides with contour $-200 \mathrm{~m}$ (b.s.l), which often represents that last major subsidence of the Ghor floor/Dead Sea as a result of the Upper Pleistocene tectonics. By contrast, the break of slope (900 - $1000 \mathrm{~m}$ a.s.l) represents the morphological discontinuity between the preserved Upper-Miocene Pliocene surface and the dissected scarp zone overlooking the Jordan Rift. Here, the surface slopes at $1^{\circ}-3^{\circ}$, while the slope of the land between 600 and $500 \mathrm{~m}$ (a.s.l) is about $15^{\circ}$. However, slopes steepened dramatically towards the faulted-erosional scarp overlooking the Dead Sea rift to reach $50^{\circ}$ [55]. $75^{\circ}$ were recorded for the hogback ridges resulting from erosion in the Ed-Dhira flexure close to Ghor Mazra. The longitudinal profile (Figure 9) of W. Kerak shows that the stream is far from attaining grade, where major interruptions exist along the profile. Although several breaks may be attributed to local variations in rock resistence, at least four major interruptions are considered as rejuvenation points (1000 m; $700 \mathrm{~m} ; 300 \mathrm{~m}$ a.s.l; $(-100)$ - ( -250$) \mathrm{m}$ b.s.l), since they coincide with at least three other wadi profiles to the north and south of W. Kerak. This fact is supported by the major breaks (1000 m; $900 \mathrm{~m} ; 800 \mathrm{~m} ; 700 \mathrm{~m} ; 600$ - $500 \mathrm{~m}$ a.s.l) observed on the projected profiles (Figure 10) for W. Kerak [55]. The major interruptions characterized the longitudinal profile of the wadi, and the presence of incised meanders (intrenched meanders close to Kerak city, and ingrown meanders to the west of Mazar town) in the middle and upper catchment indicate that rejuvenation processes occurred when the wadi was in the

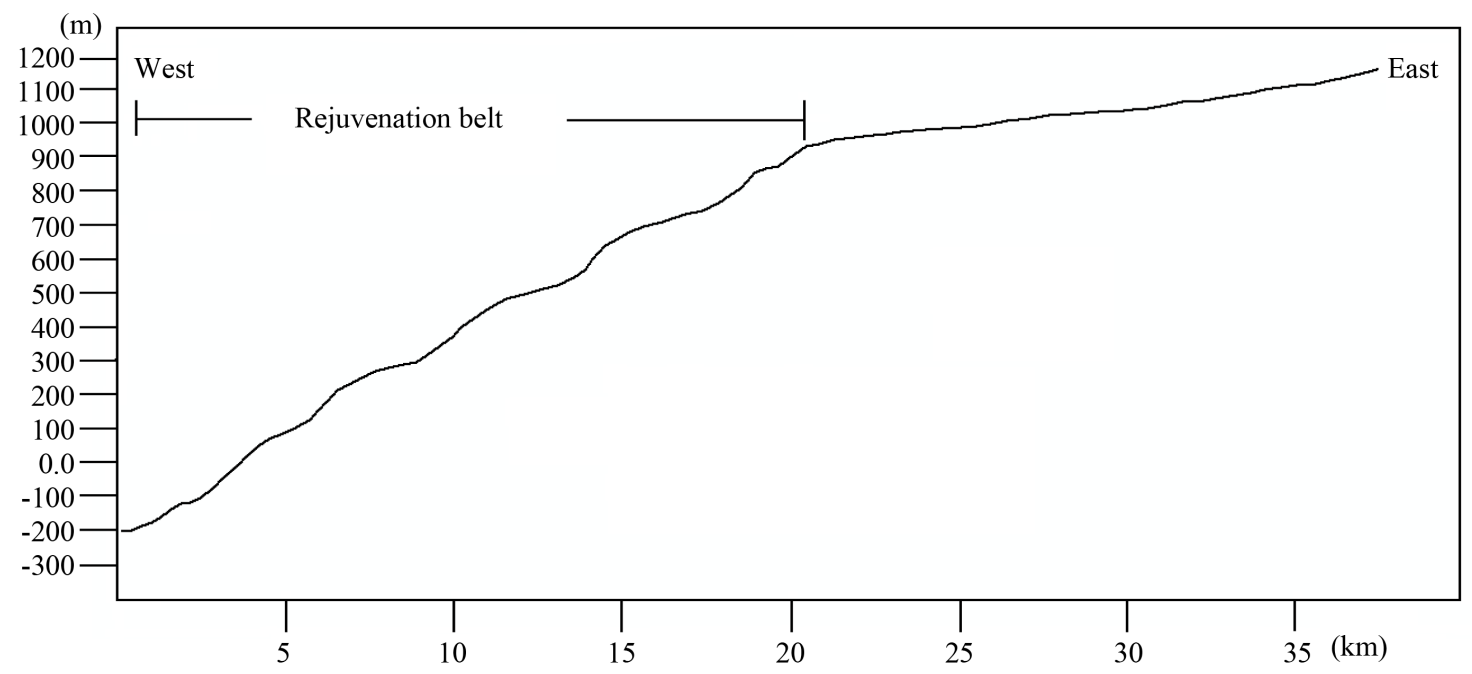

Figure 9. Major irregularities along the longitudinal profile of W. Kerak across the rejuvenation belt.

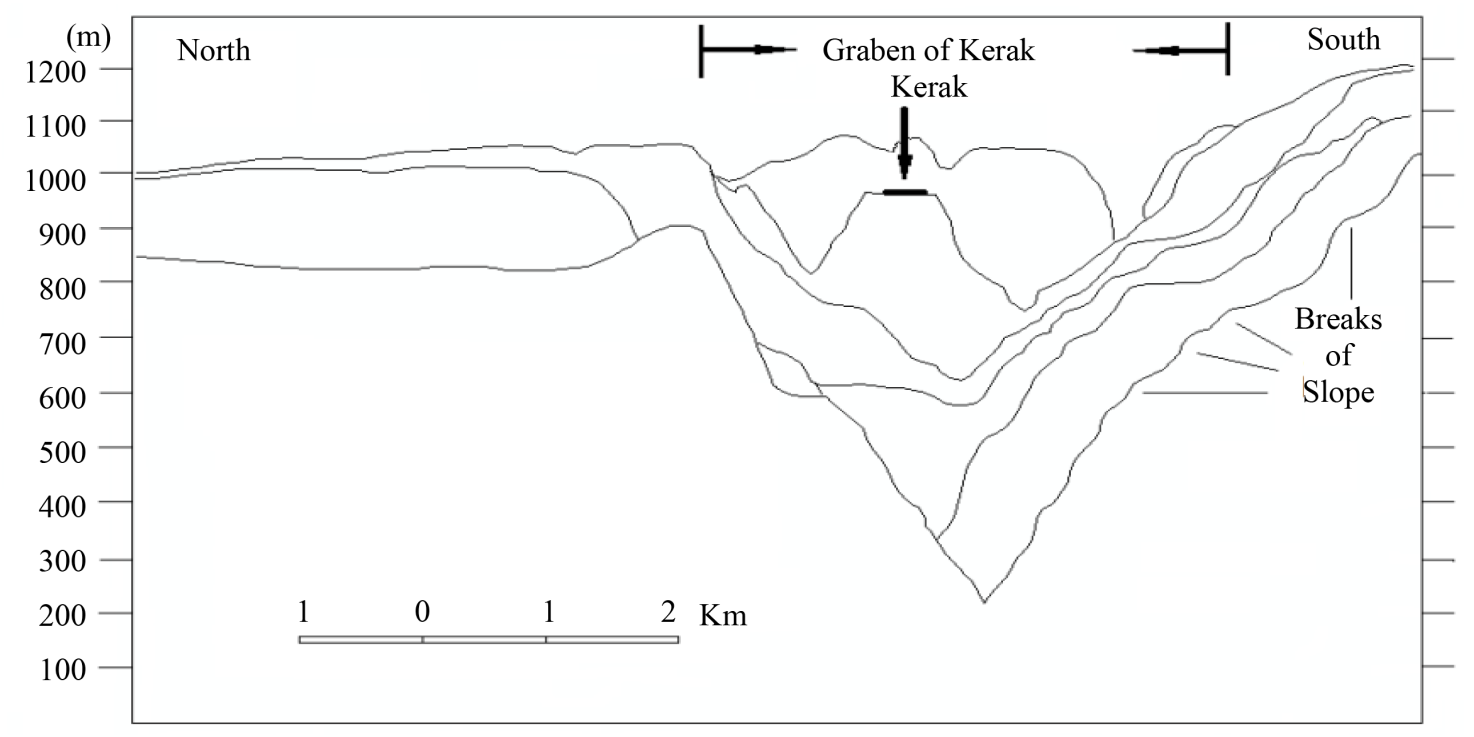

Figure 10. Major slope breaks illustrate rejuvenation stages affected W. Kerak watershed. 
nature stage of its evolution, probably at the middle of Pleistocene. These nick points and valley-side slope discontinuities truncated the upper Miocene-Pliocene surface [73], and may have originated during the lower Pleistocene tectonics, while the lower breaks between $-100 \mathrm{~m}$ to $-250 \mathrm{~m}$ b.s.l are probably attributed to the upper Pleistocene tectonics [76]. The hypsometric curve shows three different slope elements, and the breaks of slope lie at about 900 - 1000 and -250 m (Figure 6); each lie about a third-point of the curve, or the present total relief of the basin. Also, the clinographic curve immediately illustrates the three slope elements (Figure 7). Such distinctive and separate slope elements are considered a true mirror of tectonic uplifting and rejuvenation, which resulted in a "Poly-Cyclic" drainage basin as suggested earlier by Chorely [77]. The hypsographic curve for Wadi Kerak is resembles the clinographic curve. Both of them exhibit the major breaks of slope which indicate the tectonic movements and rejuvenation activity.

3) The Entrance Angle $\left(Z_{c}\right)$ Parameter Horton [7] refers to the significance of entrance angles in drainage basin development, and recognized that the course followed by a new tributary is governed by the slope of the ground over which it flows, and the gradient of the channel to which it is tributary. Where the ground slope is great in relation to the gradient of the master steam (i.e. during the youth stage of gemorphological development) a tributary joins at almost a right angle; where the master stream gradient and valley-side slope are almost the same (i.e. mature stage) the tributary almost parallels the main channel, joining it at a small angle. The idea formulated by Horton has been tested in the field by Schumm [14] on drainage basins in Perth Amboy, New Jersey. He measured 32 entrance angles for a youthful drainage basin, and found that the mean angles was $65^{\circ}$, while the mean entrance angles measured for a mature basin was $46^{\circ}$ (for 29 angles measured). He concluded that the decrease of angles of junction will be accomplished by lateral migration of the tributary towards the main channel and down-valley shift of the junction.

A sample of a twenty-angles tributary junction was measured from the W. Kerak topographic map. The frequency distribution histogram is illustrated in (Figure 11). It was found that the mean angle of junction is $67^{\circ}$, and half of the entrance angles was around $80^{\circ}$. Such results imply that W. Kerak is in the youth-age stage of erosional development with a high relief ratio, and the main stream and tributaries are controlled by the KerakAl-fiha major fault and the subsidiary dense branching faults respectively [55]. Thus, it can be deduced from existing pattern of entrance angels, that the future pattern of mean entrance angles will gradually decreased due to the process of degradation. When the junction angle becomes very small, lateral planation removes the intervening divide, and the junction migrates upstream while approaching the mature stage of development [14].

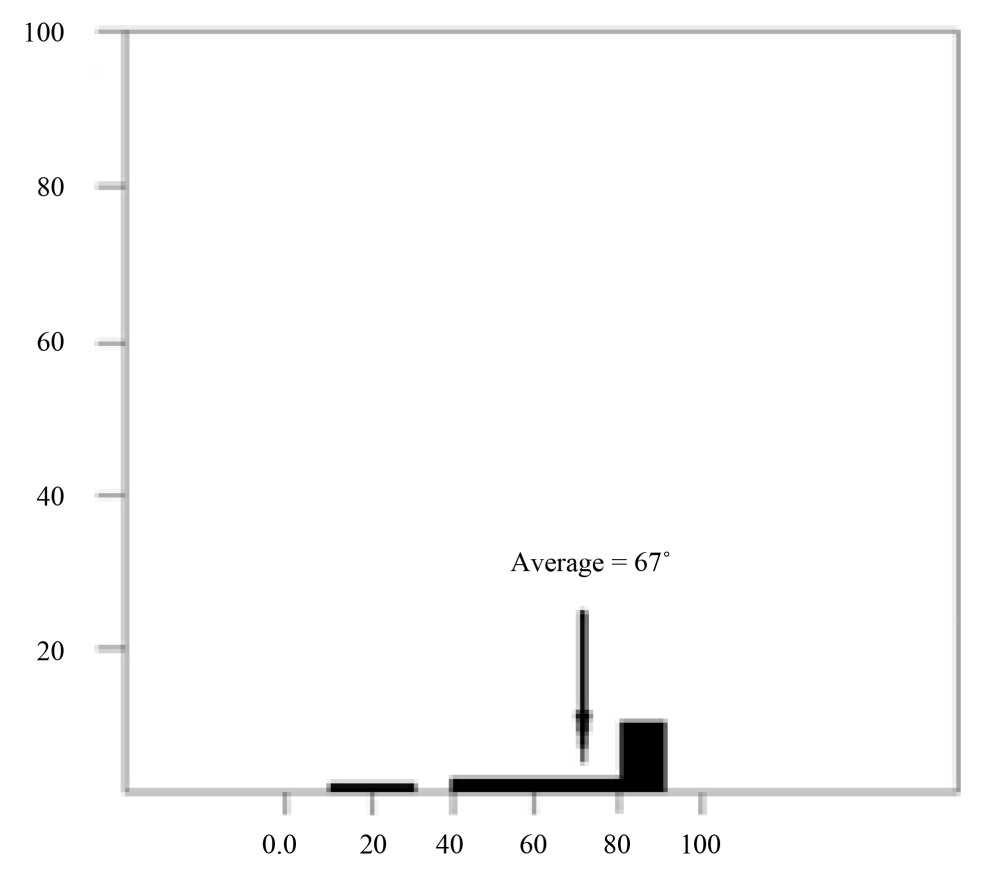

Figure 11. Frequency distribution histogram shows the values of stream-entrance angles in W. Kerak watershed. 


\section{Conclusions}

The quantitative and qualitative analysis of geomorphometric parameters for the W. Kerak watershed and five sub-basins justifies the utilization of DEM and GIS tools for geomorphic evaluation of a drainage basin located in the rift region. The drainage network of the wadi has been significantly influenced by geomorphic, lithologic, tectonic and structural factors. Morphometric analysis illustrates how these factors affected the processes of landforms development. The drainage network of the basin is mainly trellis with sub-dendritic types, and the watershed has been classified as a fifth-order basin. The drainage density $\left(D_{d}\right)$ value for the basin is 2.6, and the $D_{d}$ values for the sub-basins are below 3 which indicates that the fissured and jointed rock strata are relatively permeable, a characteristic feature of coarse drainage. The stream length ratio varies for both the W. Kerak catchment and the sub-basins as a result of local variation in morphology (changes and breaks of slope), slope steepness, relief and the stage of geomorphic evolution of landforms. High values of bifurcation ratios indicated strong structural control in the drainage pattern and stream-entrance angles. Low values of stream frequency denote that a significant proportion of surface water infiltrates to the subsurface strata, and thus the groundwater potential is relatively high. The high relief ratio is an indicator of active erosion processes or steep slopes especially in the middle and lower reaches of the catchment. Morphometric indices demonstrate a high dissected index $(\mathrm{Di}=1.3)$ and a high ruggedness number $\left(\mathrm{R}_{\mathrm{n}}=4.24\right)$ as a result of uplifting and rejuvenation which occurred during the denudational history of W. Kerak. High hypsometric integral and high values of stream-entrance angles, and prominent breaks in longitudinal, clinographic and projected profiles indicate that the W. Kerak catchment is greatly affected by rejuvenation phases. Rejuvenation experienced by the watershed existed in the variation of morphometric properties of drainage network, relief, slope gradient and profiles.

Field observations verify the results of morphometric analysis. The elongated nature of the entire catchment reveals the dominance of steep slopes and strong relief. The basin is rugged and highly dissected with high susceptibility to landslide events and soil erosion. It is also characterized by a high response to an increase in peak discharge, and high potential of surface runoff.

Reasonable infiltration capacity resulted in relatively high groundwater potential at the middle part of the basin. The geomorphometric characteristics of the rift watersheds (including the W. Kerak catchment) are remarkably different from those watersheds ending in inland depressions (i.e. El-Jafr and Azraq depressions) and the Gulf of Aqaba, southern Jordan. The knowledge gained from the present study is aimed to help decision makers in planning efficient soil and water conservation schemes, and watershed and natural resources management for future sustainable development on the catchment level.

\section{References}

[1] Chorely, R. (1971) The Drainage Basin as the Fundamental Geomorphic Unit. In: Chorely, R., Ed., Introduction to Fluvial Processes, Methuen and Co. Ltd., London, 30-52.

[2] Hlaing, K., Haruyama, S. and Aye, M. (2008) Using GIS Based Distributed Soil Loss Modeling and Morpometric Analysis to Prioritize Watersheds for Soil Conservation in Bago River Basin of Lower Myanmar. Frontiers of Earth Science in China, 2, 465-478. http://dx.doi.org/10.1007/s11707-008-0048-3

[3] Patel, D., Dholakia, M., Naresh, N. and Srivastava, P. (2012) Water Harvesting Structure Positioning by Using GeoVisualization Concept and Prioritization of Mini-Watersheds through Morphometric Analysis in the Lower Tapi Basin. Journal of the Indian Society of Remote Sensing, 40, 299-312. http://dx.doi.org/10.1007/s12524-011-0147-6

[4] Patel, D., Gajjar, C. and Srivastava, P. (2013) Prioritization of Malesari Mini-Watersheds through Morphometric Analysis: A Remote Sensing and GIS Perspective. Environmental Earth Sciences, 69, 2643-2656. http://dx.doi.org/10.1007/s12665-012-2086-0

[5] Chopra, R., Dhiman, R.D. and Sharma, P.K. (2005) Morphometric Analysis of Sub-Watersheds in Gurdaspur District, Punjab Using Remote Sensing and GIS Techniques. Journal of the Indian Society of Remote Sensing, 33, 531-539. http://dx.doi.org/10.1007/BF02990738

[6] Horton, R. (1932) Drainage Basin Characteristics. Transactions, American Geophysical Union, 13, 350-361. http://dx.doi.org/10.1029/TR013i001p00350

[7] Horton, R. (1945) Erosional Development of Streams and Their Drainage Basins; Hydrophysical Approach to Quantitative Morphology. Geological Society of America Bulletin, 56, 275-370. http://dx.doi.org/10.1130/0016-7606(1945)56[275:EDOSAT]2.0.CO;2

[8] Strahler, A. (1952a) Dynamic Basis of Geomorphology. Geological Society of America Bulletin, 63, 923-938. http://dx.doi.org/10.1130/0016-7606(1952)63[923:DBOG]2.0.CO;2 
[9] Strahler, A. (1952b) Hypsometric (Area-Altitude) Analysis of Erosional Topography. Geological Society of America Bulletin, 63, 1117-1142. http://dx.doi.org/10.1130/0016-7606(1952)63[1117:HAAOET]2.0.CO;2

[10] Strahler, A. (1957) Quantitative Analysis of Watershed Geomorphology. Transactions, American Geophysical Union, 38, 913-920. http://dx.doi.org/10.1029/TR038i006p00913

[11] Strahler, A. (1964) Quantitative Geomorphology of Drainage Basins and Channel Networks. In: Chow, V., Ed., Handbook of Applied Hydrology, McGraw Hill, New York, 439-476.

[12] Smith, K. (1950) Standards for Grading Textures of Erosional Topography. American Journal of Science, 248, 655-668. http://dx.doi.org/10.2475/ajs.248.9.655

[13] Miller, V. (1953) A Quantitative Geomorphic Study of Drainage Basin Characteristics in the Clinch Mountain Area, Virginia and Tennessee. Project NR 389-402, Technical Report 3, Columbia University, Department of Geology, ONR, New York.

[14] Schumm, S. (1956) Evolution of Drainage Systems and Slopes in Badlands at Perth Amboy, New Jersey. Geological Society of America Bulletin, 67, 597-646. http://dx.doi.org/10.1130/0016-7606(1956)67[597:EODSAS]2.0.CO;2

[15] Kouli, M., Vallianatos, F., Soupios, P. and Alexakis, D. (2007) GIS-Based Morphometric Analysis of Two Major Watersheds, Western Crete, Greece. Journal of Environmental Hydrology, 15, 1-17.

[16] Clark, J. (1966) Morphometry from Maps. In: Dury, G.H., Ed., Essays in Geomorphology, Heinemann, London, 235274.

[17] Nageswara, R., Swarna, L., Arun, K. and Hari, K. (2010) Morphometric Analysis of Gostani River Basin in Andhra Pradesh State, India Using Spatial Information Technology. International Journal of Geomatics and Geosciences, 1, 179-187.

[18] Ivanoua, E., Nedkov, R., Ivanova, I. and Radeva, K. (2012) Morpho-Hydrographic Analyze of Black Sea Catchment Area in Bulgaria. Procedia Environmental Sciences, 14, 143-153. http://dx.doi.org/10.1016/j.proenv.2012.03.014

[19] Thomas, J., Joseph, S., Thrivikramji, K., Abe, G. and Kannan, N. (2012) Morphometrical Analysis of Two Tropical River Basins of Contrasting Environmental Settings, the Southern Western Ghats, India. Environmental Earth Sciences, 66, 2353-2366. http://dx.doi.org/10.1007/s12665-011-1457-2

[20] Manu, M. and Anirudhan, S. (2008) Drainage Characteristics of Achankovil River Basin, Kerala. Journal of the Geological Society of India, 71, 841-850.

[21] Arnous, M., Aboulela, H. and Green, D. (2011) Geo-Enviornmental Hazards Assessment of the North Western Gulf of Suez, Egypt. Journal of Coastal Conservation, 15, 37-50. http://dx.doi.org/10.1007/s11852-010-0118-z

[22] Youssef, A., Pradhan, B. and Hassan, A. (2011) Flash Flood Risk Estimation along the St. Katherine Road, Southern Sinai, Egypt Using GIS Based Morphometry and Satellite Imagery. Environmental Earth Sciences, 62, 611-623. http://dx.doi.org/10.1007/s12665-010-0551-1

[23] Abdel-Lattif, A. and Sherief, Y. (2012) Morphometric Analysis and Flash Floods of Wadi Sudr and Wadi Wardan, Gulf of Suez, Egypt: Using Digital Elevation Model. Arab Journal of Geosciences, 5, 181-195. http://dx.doi.org/10.1007/s12517-010-0156-8

[24] Ozdemir, H. and Bird, D. (2009) Evaluation of Morphometric Parameters of Drainage Networks Derived from Topographic Maps and DEM in Point of Floods. Environmental Geology, 56, 1405-1415. http://dx.doi.org/10.1007/s00254-008-1235-y

[25] Abdallah, F., El Shamy, I., Bamousa, A., Mansour, A., Mohamed, A. and Tahoom, M. (2014) Flash Floods and Groundwater Recharge Potentials in Arid Land Alluvial Basins, Southern Red Sea Coast, Egypt. International Journal of Geosciences, 5, 971-982. http://dx.doi.org/10.4236/ijg.2014.59083

[26] Esper Angillieri, M. (2008) Morphometric Analysis of Colanguil River Basin and Flash Flood Hazard, San Juan, Argentina. Environmental Geology, 55, 107-111. http://dx.doi.org/10.1007/s00254-007-0969-2

[27] Markose, V. and Jayappa, K. (2011) Hypsometric Analysis of Kali River Basin, Karnataka, India, Using Geographic Information System. Geocarto International, 26, 553-568. http://dx.doi.org/10.1080/10106049.2011.608438

[28] Singh, O., Sarangi, A. and Sharma, M. (2008) Hypsometric Integral Estimation Methods and Its Relevance on Erosion Status of North-Western Lesser Himalayan Watersheds. Water Resources Management, 22, 1545-1560. http://dx.doi.org/10.1007/s11269-008-9242-z

[29] Sujatha, E., Selvakumar, R., Rojasimman, U. and Victor, R. (2013) Morphometric Anlysis of Sub-Watershed in Parts of Western Ghats, South India Using ASTER DEM. Geomatics, Natural Hazards and Risk, 6, 326-341. http://dx.doi.org/10.1080/19475705.2013.845114

[30] Rais, S. and Javed, A. (2014) Identification of Artificical Recharge Sites in Manchi Basin, Eastern Rajasthan (India) Using Remote Sensing and GIS Techniques. Journal of Geographic Information System, 6, 162-175. http://dx.doi.org/10.4236/jgis.2014.62017 
[31] Mather, P. and Doornkamp, J. (1970) Mutivariate Analysis in Geography with Particular Reference to Drainage-Basin Morphometry. Transactions of the Institute of British Geographers, 51, 163-187. http://dx.doi.org/10.2307/621768

[32] Doornkamp, J. and King, C. (1971) Numerical Analysis in Geomorphology: An Introduction. Edward Arnold, London.

[33] Kumar, R., Kumar, S., Lohani, A., Nema, R. and Singh, R. (2000) Evaluation of Geomorphological Characteristics of a Catchment Using GIS. GIS India, 9, 13-17.

[34] Yunus, A., Oguchi, T. and Hayakawa, Y. (2014) Morphometric Analysis of Drainage Basins in the Western Arabian Peninsula Using Multivariate Statistics. International Journal of Geosciences, 5, 527-539. http://dx.doi.org/10.4236/ijg.2014.55049

[35] El Maghraby, M., Masoud, M. and Niyazi, B. (2014) Assessment of Surface Runoff in Arid, Data Scarce Regions; An Approach Applied in Wadi Al Hamd, Al Madinal al Munawarah, Saudi Arabia. Life Science Journal, 11, 271-289.

[36] Baumgardner, R. (1987) Morphometric Studies of Sub-Humid and Semiarid Drainage Basin, Texas Panhandle and Northeastern New Mexico. University of Texas Bureau of Economic Geology, Austin, Report of Investigations, 163.

[37] Gardiner, V. (1990) Drainage Basin Morphometry. In: Goudie, A., Ed., Geomorphological Techniques, Unwin Hyman, London, 71-81.

[38] Patton, P. (1988) Drainage Basin Morphometry and Floods. In: Baker, V., Kochel, R. and Patton, P., Eds., Flood Geomorphology, Wiley, New York, 51-65.

[39] Silva, A., Herpin, U. and Martinelli, L. (2006) Morphometric Characteristics of Seven Meso-Scale River Basins in State of Sao Paul (Southeastern Brazil). Caminhos de Geografia, 3, 20-30.

[40] Abrahams, A. (1984) Channel Networks: A Geomorphological Perspective. Water Resources Research, 20, $161-188$. http://dx.doi.org/10.1029/WR020i002p00161

[41] Mark, D. (1983) Relations between Field-Surveyed Channel Network and Map-Based Geomorphometric Measures, Inez Kentucky. Annals of the Association of American Geographers, 73, 358-372. http://dx.doi.org/10.1111/j.1467-8306.1983.tb01422.x

[42] Markose, V., Dinesh, A. and Jayappa, K. (2014) Quantitative Analysis of Morphometric Parameters of Kali River Basin, Sothern India, Using Bearing Azimuth and Drainage (bAd) Calculator and GIS. Environmental Earth Sciences, 72 , 2887-2903. http://dx.doi.org/10.1007/s12665-014-3193-x

[43] Prasannakumar, V., Vijith, H. and Geetha, N. (2013) Terrain Evaluation through the Assessment of Geomorphometric Parameters Using DEM and GIS: Case Study of Two Major Sub-Watersheds in Attapady, South India. Arab Journal of Geosciences, 6, 1141-1151. http://dx.doi.org/10.1007/s12517-011-0408-2

[44] Apaydin, H., Ozturk, F., Merdun, H. and Aziz, N. (2006) Determination of the Drainage Basin Characteristics Using Vector GIS. Nordic Hydrology, 37, 129-142.

[45] Saeedrashed, Y. and Guven, A. (2013) Estimation of Geomorphological Parameters of Lower Zab Riverk-Basin by Using GIS Based Remotely Sensed Image. Water Resources Management, 27, 209-219.

http://dx.doi.org/10.1007/s11269-012-0179-x

[46] Franklin, S. (1987) Geomorphometric Processing of Digital Elevation Model. Computers \& Geosciences, 13, $603-609$. http://dx.doi.org/10.1016/0098-3004(87)90030-6

[47] Kamp, U., Bolch, T. and Olsenholler, J. (2005) Geomorphometry of Cerro Sillajhauy (Andes, Chile/Bolivia): Comparison of Digital Elevation Models (DEMs) from ASTER Remote Sensing Data and Contour Maps. Geocarto International, 20, 23-33. http://dx.doi.org/10.1080/10106040508542333

[48] Singh, P., Thakur, J. and Singh, U. (2013) Morphometric Analysis of Morar River Basin, Madhya Pradesh, India, Using Remote Sensing and GIS Techniques. Environmental Earth Sciences, 68, 1967-1977. http://dx.doi.org/10.1007/s12665-012-1884-8

[49] Farhan, Y. (1982) Slope Morphology in Central Jordan. Yarmouk University Press, Irbid. (In Arabic)

[50] Ministry of Agriculture (Jordan) (1995) The Soils of Jordan. Report of the National Soil Map and Land Use Project. Hunting Technical Services Ltd. and European Commission.

[51] Atkinson, K. and Beaumont, P. (1971) The Forests of Jordan. Economic Botany, 25, 305-311. http://dx.doi.org/10.1007/BF02860765

[52] Burdon, D. (1959) Handbook of the Geology of Jordan. Benham and Co., Colchester.

[53] Bender, F. (1975) Geology of the Arabian Peninsula: Jordan. United States Geological Survey Professional Paper 560-I, Washington DC.

[54] Farhan, Y. and Nawaysa, S. (2015) Spatial Assessment of Soil Erosion Risk in Wadi Kerak, Southern Jordan Using RUSLE and GIS Techniques. In Review.

[55] Farhan, Y. (1971) Geomorphology of Wadi Moujeb and Wadi Kerak, Central East Jordan. M.A. Thesis, University of 
Cairo, Cairo.

[56] Hanson-Lowe, J. (1935) The Clinographic Curve. Geological Magazine, 72, 180-184. http://dx.doi.org/10.1017/S001675680009258X

[57] Schumm, S. (1963) Sinuosity of Alluvial Rivers on the Great Plains. Geological Society of America Bulletin, 74, 10891100. http://dx.doi.org/10.1130/0016-7606(1963)74[1089:SOAROT]2.0.CO;2

[58] Hadley, R. and Schumm, S. (1961) Sediment Sources and Drainage Basin Characteristics in Upper Cheyenne River Basin. US Geological Survey Water-Supply Paper 1531-B, Washington DC, 198.

[59] Chorely, R., Donald, M. and Pogorzelski, H. (1957) A New Standard for Estimating Drainage Basin Shape. American Journal of Science, 255, 138-141. http://dx.doi.org/10.2475/ajs.255.2.138

[60] Singh, S. and Dubey, A. (1994) Geoenvironmental Planning of Watersheds in Indian. Chugh Publications, Allahabad, 28-69.

[61] Pareta, K. and Pareta, U. (2011) Quantitative Morphometric Analysis of a Watershed of Yamuna Basin, India Using ASTER (DEM) Data and GIS. International Journal of Geomatics and Geosciences, 2, 248-269.

[62] Prasad, R.K., Mondal, N.C., Banerjee, P., Nandakumar, M.V. and Singh, V.S. (2008) Deciphering Potential Groundwater Zone in Hard Rock through the Application of GIS. Environmental Geology, 55, 467-475. http://dx.doi.org/10.1007/s00254-007-0992-3

[63] Magesh, N.S., Chandrasekar, N. and Soundranayagam, J.P. (2011) Morphometric Evaluation of Papanasam and Manimuthar Watersheds, Part of Western Ghats, Tirunelueli Distric, Tamil Nadu, India: A GIS Approach. Environmental Earth Sciences, 64, 373-381. http://dx.doi.org/10.1007/s12665-010-0860-4

[64] Sreedevi, P.D., Sreekanth, P.D., Khan, H.H. and Ahmad, S. (2013) Drainage Morphometry and Its Influence on Hydrology in an Semi Arid Region: Using SRTM Data and GIS. Environmental Earth Sciences, 70, 839-848. http://dx.doi.org/10.1007/s12665-012-2172-3

[65] Nawaysa, S. (2006) Environmental Hazards in Wadi Kerak Catchment, Jordan. Ph.D. Dissertation, University of Jordan, Amman.

[66] Singh, S. and Singh, M.C. (1997) Morphometric Analysis of Kanhar River Basin. National Geographical Journal of India, 43, 31-43.

[67] Bishop, M., Shroder, J., Bonk, R. and Olsenholler, J. (2002) Geomorphic Change in High Mountains: A Western Himalayan Perspective. Global and Planetary Change, 32, 311-329. http://dx.doi.org/10.1016/S0921-8181(02)00073-5

[68] Singh, P., Kumar, S. and Singh, U. (2011) Groundwater Resources, Evaluation in the Gwalior Area, India, Using Satellite Data: An Integrated Geomorphological and Geophysical Approach. Hydrogeology Journal, 19, 1421-1429. http://dx.doi.org/10.1007/s10040-011-0758-6

[69] Hurtrez, J., Lucazean, F. and Avouac, J. (1999) Investigation of the Relationships between Basin Morphology, Tectonic Uplift and Denudation from the Study of an Active Fold Belt in Siwalik Hills, Central Nepal. Journal of Geophysical Research, 104, 12779-12796. http://dx.doi.org/10.1029/1998JB900098

[70] Weissel, J., Pratson, L. and Malinverno, A. (1994) The Length-Scaling Properties of Topography. Journal of Geophysical Research, 99, 13997-14012. http://dx.doi.org/10.1029/94JB00130

[71] Doranti-Tiritan, C., Hackspacher, P., de Souza, D. and Siqueira-Riberio, M. (2014) The Use of the Stream LengthGradient Index in Morphotectonic Analysis of Drainage Basins in Pocos de Caldas Plateau, SE Brazil. International Journal of Geosciences, 5, 1383-1394. http://dx.doi.org/10.4236/ijg.2014.511112

[72] Ionides, M. (1939) Report on the Water Resources of Transjordan and their Development. Crown Agents, London.

[73] Beheriy, S. (1969) Geomorphology of Central East Jordan. Bulletin de La Societe de Geographie d'Egypt, 41-42, 5-22.

[74] Sparks, B. (1972) Geomorphology. Longman, London.

[75] Balchin, W. (1937) The Erosion Surfaces of North Cornwall. The Geographical Journal, 90, 52-63. http://dx.doi.org/10.2307/1788247

[76] Quennell, A. (1958) The Structure and Geomorphic Evolution of the Dead Sea Rift. Quarterly Journal of the Geological Society, 114, 1-24. http://dx.doi.org/10.1144/gsigs.114.1.0001

[77] Chorely, R. (1958) Aspects of the Morphometry of "Poly-Cyclic” Drainage Basin. The Geographical Journal, 124, 370-374. http://dx.doi.org/10.2307/1790789 